\title{
Article \\ Passive Sampling with Active Carbon Fibres in the Determination of Organic Pollutants in Groundwater
}

\author{
Primož Auersperger ${ }^{1}$, Anja Koroša ${ }^{2, *}$, Nina Mali $^{2}$ and Brigita Jamnik ${ }^{1}$ \\ 1 JP VOKA SNAGA d.o.o., Vodovodna Cesta 90, 1000 Ljubljana, Slovenia; \\ primoz.auersperger@vokasnaga.si (P.A.); brigita.jamnik@vokasnaga.si (B.J.) \\ 2 Geological Survey of Slovenia, Dimičeva Ulica 14, 1000 Ljubljana, Slovenia; nina.mali@geo-zs.si \\ * Correspondence: anja.korosa@geo-zs.si; Tel.: +38-612-809-817
}

check for updates

Citation: Auersperger, P.; Koroša, A.; Mali, N.; Jamnik, B. Passive Sampling with Active Carbon Fibres in the

Determination of Organic Pollutants in Groundwater. Water 2022, 14, 585. https://doi.org/10.3390/w14040585

Academic Editor: Ana Rita Lado Ribeiro

Received: 20 December 2021

Accepted: 2 February 2022

Published: 15 February 2022

Publisher's Note: MDPI stays neutral with regard to jurisdictional claims in published maps and institutional affiliations.

Copyright: (C) 2022 by the authors. Licensee MDPI, Basel, Switzerland. This article is an open access article distributed under the terms and conditions of the Creative Commons Attribution (CC BY) license (https:// creativecommons.org/licenses/by/ $4.0 /)$.

\begin{abstract}
Legislation addressing the quality of groundwater and increasing concerns over public health calls for the development of analytical methods that can produce accurate and precise results at the ppt level. Passive sampling has been recognised as a helpful tool in identifying various organic pollutants in groundwater, even when their presence had not yet been identified through conventional groundwater quality monitoring. The article presents an analytical method involving a simple and cost-effective passive sampling device using Zorflex ${ }^{\circledR}$ activated carbon fibres (ACFs) for the qualitative monitoring of a broad range of organic pollutants in water in a single run. The applicability of the method developed was tested in three hydrogeological studies. In the first case, we present a non-targeted qualitative screening and a list of 892 different contaminants detected in the groundwater in Slovenia. In the second case, we discuss the presence and origin of organic compounds in the groundwater from a pilot area of the urban aquifer, Ljubljansko polje. The third case presents a comparison of results between passive and grab sampling. Passive sampling with ACFs confirmed the presence of a pollutant, even when it had not been previously detected through a quantitative method.
\end{abstract}

Keywords: GC-MS; organic pollutants; qualitative analysis; passive sampling; groundwater

\section{Introduction}

The strict EU legislation on groundwater has pushed analytical methods to new frontiers [1,2]. The main aim of this study was to develop a method for the single-shot detection of a broad range of organic compounds in relatively clean natural waters in the simplest and most cost-effective way possible. Organic compounds, identified as one of the emerging pollutant groups in groundwater, are now widely used in a range of human practices and activities. Their number is further increased by several million metabolites and degradation products of the parent compounds. Determining their concentration in groundwater is not practical or even feasible. In contrast to traditional organic pollutants, such as pesticides, aromatics, and halogenated solvents, recent research has focused on the detection of pharmaceuticals and other persistent chemicals in the environment [1-18]. As a result, a broad range of organic compounds with very diverse physicochemical properties should be analysed using techniques that approach the limit of detection (LOD), not only to determine well-defined contamination clouds, but also to obtain a clear picture of pollution at very low concentrations, or even before the first relevant signs of pollution appear. The financial framework for such analytical techniques should remain reasonably cost-effective. Various analytical methods have been developed to measure organic contaminants in water. Hyphenated gas chromatography-mass spectrometry (GC-MS) for non-polar and moderately polar organic compounds, and liquid chromatography-mass spectrometry (LC-MS) techniques for polar compounds, are the most commonly used today [1,2]. Sample preparation is one of the crucial steps in obtaining reliable results below the ppt level with minimal secondary contamination. 
The detection of contaminants in groundwater depends on the measurement approaches and techniques employed, of which two principal methods exist. The first is non-target screening (with no prior information), and the second is suspect or target screening (for suspect substances based on prior information) [19]. While non-target screening is time-consuming, it provides important information on the compounds present in the sample. On the other hand, studies that use suspect screening are published more frequently [3]. Studies of this type have identified low and variable concentrations as one of the several challenges involved in determining organic compounds in groundwater.

Interest in the principles of qualitative analysis has grown since 1997 [20,21], leading to an increase in the number of publications presenting detailed studies on screening methods [22-24], their validation, and the uncertainties associated with estimation procedures [25-28]. Screening methods were first placed in a broader analytical context with the proposal by Valcárcel and Cárdenas [29] on vanguard and rear-guard analytical strategies. Qualitative analyses are based on confirming the presence of chemical substances and providing analytical information from binary yes/no responses in a short time (e.g., detection of a chemical substance), while rear-guard analytical systems perform a complete analytical process for quantification purposes. Between these two approaches lies semi-quantitative analysis, discussed in a report by [30], which deals with the validation of qualitative and semi-quantitative methods. Ultimately, its aim was to establish an acceptable balance between being "sufficient to detect problems" and not being so extensive that it would be too costly. This practical limitation is also the main reason for not complicating validation procedures for qualitative methods [30].

However, groundwater monitoring programmes are still largely based on the collection of grab samples. This approach provides a snapshot of contamination at a particular point in time and may therefore not be truly representative of relevant environmental conditions over time. More than a decade ago, passive sampling was introduced as an attractive alternative to sampling natural waters [3,17,31-39]. In 2012, ISO 5667-23 was published as the first standard for passive sampling of surface waters, followed by ASTM D7929-14 for passive sampling of groundwater in 2014. Compared to traditional sampling methods, passive sampling is less sensitive to random extreme variations in the concentration of organic pollutants in natural waters, and a wide range of contaminants can be detected simultaneously. A passive sampler can cover a long sampling period and integrate pollutant concentrations over time. Although compared to conventional monitoring, the use of passive samplers can significantly reduce analytical costs, a validation procedure that includes an assessment of the degree of sampling uncertainty remains a challenge [15,17,40-49].

The passive sampling procedure has been proven to be a powerful tool in preliminary observations of aquifers for periodic verification of an analyte list for quantitative monitoring, for early detection of various anthropogenic impacts on aquifers, and for other hydro-geological studies [40]. In response to the lack of methods for simple and effective routine monitoring of microorganic substances, the aim of our research was to develop an analytical method using activated carbon fibre (ACF) passive sampling as a qualitative sampling method that complies with the ISO 5667-23:2011 standards for the detection of a wide range of organic compounds in groundwater by GC-MS. The positive properties of active carbon adsorption have encouraged researchers to use active carbon in virtually all areas of chemistry, mainly because of the simplicity of its design and operation, its selective tendency towards certain substances, and its complete elimination of pollutants, even from diluted solutions. This has led to an intensified search for durable, reliable, and selective alternatives for the protection and conservation of the environment $[50,51]$. This paper presents the development and application of this analytical method. Compared to other published passive sampling methods [8,31,41,49,52-63], the described procedure is one of the simplest and most efficient amongst those that allow for the detection of a wide range of organic compounds.

The development of new sampling and analytical methods or approaches is of great importance for hydrogeological studies. In groundwater, most pollutants are usually 
present at concentrations below the limit of quantification (LOQ), some of them also below the limit of detection (LOD) in the ppt and sub-ppt range. To date, researchers have investigated a wide range of emerging pollutants in groundwater, searched for possible sources of pollution, and studied the dynamics of pollution in aquifers and similar environments $[15,64,65]$. Many of these studies are difficult to transfer to larger areas due to the cost of the analyses, as well as sampling and transport issues. The optimisation of precisely these aspects was the main goal of our research.

The applicability of the ACF method has been tested in various groundwater quality studies. This article presents the following three examples of its applicability: (a) detection of a wide range of organic compounds in groundwater at a regional scale, (b) the results of passive ACF sampling designed to analyse the possible source of contamination in the aquifer used for public water supply, and (c) comparison of grab and passive sampling results. In particular, we wanted to test whether this method could be used to detect organic compounds that had not been previously detected in the analysis of grab samples, i.e., emerging compounds.

The objectives of the present study were as follows: (a) to develop a non-target screening method that is simple and repeatable with the GC-MS analysis; (b) to simultaneously detect the presence of a wide spectrum of organic pollutants in groundwater; (c) to detect the presence of numerous organic pollutants, including those not yet detected by conventional analytical methods; (d) to apply the developed method in the field to investigate the origin and occurrence of organic pollutants in aquifers.

\section{Materials and Methods}

\subsection{Chemicals and Reagents}

Pure standards and standard solutions of analytes were purchased from Dr. Ehrenstorfer (Augsburg, Germany) and C/D/N Isotopes Inc. (Pointe-Claire, QC, Canada); MTBSTFA and t-BDMCS were obtained from Acros Organics (Geel, Belgium). Dichloromethane (DCM), HPLC special grade, acetone HPLC, and methanol $(\mathrm{MeOH})$ were purchased from Rathburn Chemicals Ltd. (Walkerburn, UK). Ultra-pure water (UPW) used for AFC storage was purchased from EASYpure LF (Barnstead Thermolyne International, Dubuque, IA, USA).

All-glass syringes were obtained from Poulten \& Graf (Wertheim-Reinhardshof, Germany), PTFE membrane filter, $0.2 \mu \mathrm{m}$ from Sartorius AG (Göettingen, Germany), all-glass test tubes and weighing bottles from Lenz Laborglas (Wertheim, Germany); and helium (99.9\%) and nitrogen gas (99.9\%) from Messer Slovenija d.o.o. (Ruše, Slovenia). An SPE vacuum unit for evaporation of 12 samples was obtained from Grace/Alltech (Deerfield, MA, USA) and a Swinny filter holder (13 mm, stainless steel) from Merck (Darmstadt, Germany).

\subsection{Sample Preparation}

Zorflex ${ }^{\circledR}$ FM10 active carbon fibres (ACFs) for passive sampling devices (Figure 1), were purchased from Calgon Carbon Corporation (Pittsburgh, PA, USA). ACFs were used as a strong and reliable adsorbent [50]. In one day, approximately 8 samples could be analysed in a GC-MS run consisting of samples, quality controls, and with a pure DCM analysis between each two samples.

\subsubsection{ACF Purification and Transport to Sampling Site}

Before installation, appropriate portions $\left(3 \mathrm{~cm}^{2}\right.$ each) of ACFs were heated for three hours at $300{ }^{\circ} \mathrm{C}$ in clean air from IQAir air purifiers. ACFs were transferred to the test tubes using tweezers and were not allowed to cool. Before cooling, a few drops of ultrapure water (UPW) were added to generate steam. The test tubes were then filled with UPW and sealed. The sealed test tubes were put in a flask with UPW and active carbon at the bottom of the flask and then transported to the installation point. 


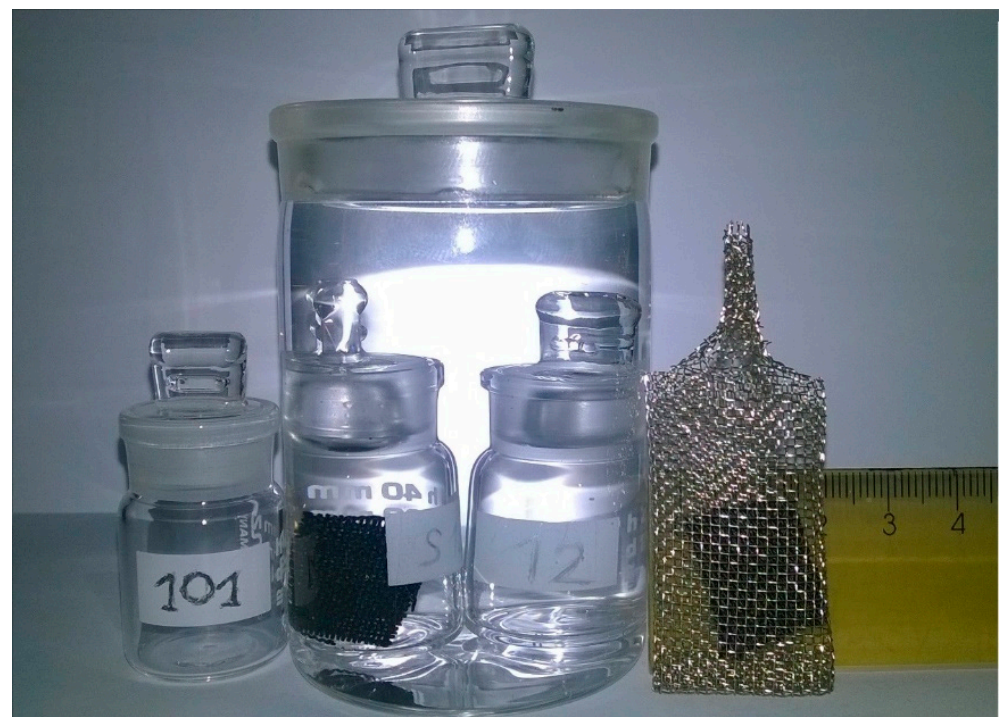

Figure 1. Weighing bottles filled with UPW for the transport of passive samplers and stainless steel casing with ACFs.

\subsubsection{ACF Deployment}

At the installation point, stainless steel meshes were equipped with ACFs just before installation (Figure 1). All stainless steel materials used for ACF installation were purchased from MDM (Ljubljana, Slovenia). Stainless steel mesh was used for the passive sampler casing and was installed in an appropriately deep borehole on a stainless steel wire. Groundwater temperature, electrical conductivity, $\mathrm{pH}$, and total organic carbon (TOC) were measured before and after installation of the passive sampler.

\subsubsection{ACF Collection and Elution of Compounds}

After exposure of passive sampling devices, the ACFs were immediately transferred out of their casings to weighing bottles filled with UPW using tweezers and transported to the laboratory in additional weighing bottles filled with UPW.

\subsubsection{Elution of Compounds from ACFs}

The UPW from the weighing bottles was removed and the ACFs were dried in an oven at $100{ }^{\circ} \mathrm{C}$ for one hour. The $3 \mathrm{~mL}$ of extraction solvent (DCM with $5 \% \mathrm{MeOH}$ ), along with internal standards caffeine-D9, phenol-D5, estrone-D4, and cholesterol-D4, was added to the weighing bottles for the elution of compounds, which was performed in an ultrasonic bath for $30 \mathrm{~min}$. Approx. $2 \mathrm{~mL}$ of the remaining extraction solvent was collected in a syringe, filtered into a chromatographic vial, and concentrated to approx. $50 \mu \mathrm{l}$ by nitrogen steam. As an alternative, derivatisation using a mixture of $\mathrm{N}$-(t-butyldimethylsilyl)- $\mathrm{N}$ methyltrifluoroacetamide (MTBASTFA) and 1\% tert-butyldimethylsilyl chloride (t-BDMCS) was performed directly from the ACFs with the addition of $100 \mu \mathrm{l}$ of a derivatisation reagent by reaction in an ultrasonic bath for $1 \mathrm{~h}$, followed by the addition of $3 \mathrm{~mL}$ of extraction solvent and the elution of compounds in an ultrasonic bath for an additional $30 \mathrm{~min}$. Two ACFs were installed at the same sample location in order to perform the derivatisation on one of them.

\subsection{Analytical Method-Chromatographic Analysis}

All samples were analysed using gas chromatography with mass spectrometry (GC-MS) (GC 6900/QP 5890, Agilent, Folsom, CA, USA) using a GERSTEL autosampler (Mülheim an der Ruhr, Germany) and a GC-MS Clarus 600 (PerkinElmer, Waltham, MA, USA), with a CombiPAL Autosampler (CTC analytics, Zwingen, Switzerland). Silanized injection liners with silanized glass wool were procured from SGE International Pty Ltd. (Ringwood, Australia), a DB- $5 \mathrm{~ms}$ ultra inert column, $30 \mathrm{~m} \times 0.25 \mathrm{~mm}$ I.D., df $0.25 \mu \mathrm{m}$ from Agilent (J\&W 
Scientific (Folsom, CA, USA)); IQAir GCX air purifiers (INCEN AG, Staad, Switzerland); and an HP-5MS UI column, $30 \mathrm{~m}$ I.D. $0.25 \mathrm{~mm}$, df $0.25 \mu \mathrm{m}$ from Agilent.

The operational settings for Agilent GC-MS were as follows: Inlet at $270{ }^{\circ} \mathrm{C}$; transfer line at $280^{\circ} \mathrm{C}$; ion source at $250{ }^{\circ} \mathrm{C}$; quadrupole at $150{ }^{\circ} \mathrm{C}$. Injection: $2 \mu$ l pulsed splitless (pressure, $300 \mathrm{kPa}$ for $1 \mathrm{~min}$ ). Carrier gas flow: $\mathrm{He}, 1.0 \mathrm{~mL} / \mathrm{min}$ (constant flow). Total flow of $54 \mathrm{~mL} / \mathrm{min}$. Oven program: $35^{\circ} \mathrm{C}(1 \mathrm{~min})$ to $270{ }^{\circ} \mathrm{C}$, with a total run time of $46.0 \mathrm{~min}$. Total ion chromatogram (TIC) from 30 to $750 \mathrm{~m} / z$.

Operational settings for the Perkin Elmer GC-MS were as follows: Inlet at $80^{\circ} \mathrm{C}$, after injection to $280{ }^{\circ} \mathrm{C}$; transfer line at $280{ }^{\circ} \mathrm{C}$; ion source at $250{ }^{\circ} \mathrm{C}$; injection: $8 \mu \mathrm{l}$ pulsed splitless (column flow $5 \mathrm{~mL} / \mathrm{min}$ for $2 \mathrm{~min}$ ); carrier gas flow: $\mathrm{He}, 1.0 \mathrm{~mL} / \mathrm{min}$ (constant flow after $2 \mathrm{~min}$ ); total flow $53 \mathrm{~mL} / \mathrm{min}$ after $1.5 \mathrm{~min}$; oven program: $35{ }^{\circ} \mathrm{C}$ (1 min) to $280{ }^{\circ} \mathrm{C}$, with a total run time of $50.0 \mathrm{~min}$. TIC from 30 to $750 \mathrm{~m} / \mathrm{z}$.

Chemstation and Agilent Deconvolution Reporting Software (DRS) with retention time library 5989-5076EN (Agilent) and NIST 2008 spectral library and TurboMass software (PerkinElmer) and NIST 2008 spectral library were used for the interpretation of chromatograms. The GC-MS chromatograms were interpreted in two different ways. The first consisted of both a manual and an automatic evaluation of chromatograms to search for compounds. The results for the detected compounds were ranked on a scale from one (lowest) to five (highest) according to peak relative intensity compared to other peaks in the same GC-MS chromatogram. Only a few compounds with a maximal peak (5) area were reported. Others were ranked between two and four by the operator, according to their peak areas. Additional results from AMDIS deconvolution covered by commercial databases were also reported with rank-1 compounds.

The second evaluation of GC-MS chromatograms employed the integration of the most abundant mass fragments from the discovered compounds of interest, with the mass fragment $m / z 203$ of caffeine-D10 used as an "internal standard". Ratios between the areas for compounds of interest and caffeine-D10 were calculated. Caffeine-D10 was chosen owing to its good mass spectrum definiteness and moderate polarity, which is similar to the average polarity values for the compounds of interest. The relationship allows for the comparison of different groundwater samples; consequently, the spatial distribution of the compounds can also be determined and shown.

\subsection{Quality Control}

The field and laboratory blank passive samplers were prepared, extracted, and analysed in parallel with each exposed sampler for quality control (QC) of the analytical method.

\subsubsection{Sampling QC Procedure}

Field blanks were tested by exposing the passive samplers to air at each installation point. The blanks were transported to the laboratory in the same way as the samples and were retained in the laboratory until the passive samplers were collected. Once the passive samplers were collected, the procedure was repeated using the blanks. The blanks were then analysed in the same way as the samples.

\subsubsection{Analytical QC Procedure}

Targeting retention times and signal-to-noise $(\mathrm{S} / \mathrm{N})$ calculations were subjected to the following quality controls: A first quality control solution (QC1) containing more than 100 semi-volatile compounds and a second quality control solution (QC2) of volatiles in DCM were injected using the same method. These compounds had similar physical and chemical properties as the compounds from QC4 (Table 1). A $5 \mathrm{mg} / \mathrm{L}$ solution of endrine and $\mathrm{p}, \mathrm{p}^{\prime}$-DDT was used as a third quality control solution (QC3) to test the degradation of sensitive compounds according to the EPA 525.2 method. Maintenance on the injection port was performed if the degradation exceeded $20 \%$ of the parent compounds. 
Table 1. Composition of control solution QC4 and results of the analysis with results of repeatability experiments with 6 samples of QC4 and removal efficiency for compounds.

\begin{tabular}{|c|c|c|c|c|c|c|c|}
\hline \multirow[t]{2}{*}{ Compound } & \multirow[t]{2}{*}{ CAS NO } & \multirow{2}{*}{$t_{r}, \min$} & $m / z$ & $\begin{array}{l}\text { Intensity } \\
\text { Estimate }\end{array}$ & A (avg) & \multirow[t]{2}{*}{ RDS (\%) } & \multirow{2}{*}{$\begin{array}{c}\% \text { in } \\
\mathbf{A}_{\mathrm{KPV}} / \mathbf{A}_{(\text {max.)blank }}\end{array}$} \\
\hline & & & (QVN/QLN) & $(1-5)$ & $($ for $Q V N ~ m / z)$ & & \\
\hline Benzene & $71-43-2$ & 2.5 & $78 / 51$ & 3 & $25,220,508$ & 34 & 5.9 \\
\hline 1,2,4-trichlorobenzene & $120-82-1$ & 8.3 & $180 / 145,109$ & 5 & $18,051,177$ & 34 & 0.022 \\
\hline $\begin{array}{l}\text { Chlorotoluron } \\
\text { (as 3-chloro-4- } \\
\text { methylphenylisocyanate) }\end{array}$ & $\begin{array}{c}15545-48-9 \\
(28479-22-3)\end{array}$ & 8.8 & $167 / 132,104$ & 2 & $1,152,915$ & 51 & 0.11 \\
\hline 1-methyl-1H-benzotriazole & $13351-73-0$ & 10.3 & $133 / 10,590$ & 5 & $29,498,504$ & 47 & 0.072 \\
\hline Atrazine & $1912-24-9$ & 14 & $200 / 215,173$ & 3 & $8,552,177$ & 54 & 0.015 \\
\hline Caffeine & $58-08-2$ & 16 & $194 / 10,967$ & 3 & $5,557,887$ & 54 & 0.22 \\
\hline Propyphenazone & $479-92-5$ & 17.5 & $215 / 230$ & 3 & $20,360,628$ & 68 & 0.078 \\
\hline Carbamazepine & $298-46-4$ & 25.9 & $193 / 236,165$ & 3 & 196,786 & 73 & N.D.* \\
\hline Estrone & $53-16-7$ & 32.5 & $270 / 185,146$ & 2 & 435,79 & 85 & N.D.* \\
\hline
\end{tabular}

Notation: $m / z$-mass-to-charge ratio; QVN- $m / z$, which was used to calculate areas for A/AIS ratios; QLN- $m / z$, which were used to confirm identity; CAS NO-chemical abstract service number; * N.D.- not detected; RSD_relative standard deviation.

Before the installation of passive samplers, the purity and adsorption capacity of each series were tested with two control solutions (QC4 solution and QC5 solution), whose compositions were selected according to their physio-chemical properties in order to represent a whole range of compounds of interest. In the QC4, $5 \mu \mathrm{l}$ of the standard solution of analytes at approx. $100 \mathrm{mg} / \mathrm{L}$ from Table 1 was added to $20 \mathrm{~mL}$ of UPW. A second control solution (QC5) was used for derivatisation, where $5 \mu$ l of a standard solution of analytes at approx. $100 \mathrm{mg} / \mathrm{L}$ from Table 2 was added to $20 \mathrm{~mL}$ of UPW. The results for both control solutions are presented in Tables 1 and 2. The TIC of both control solutions-QC4 and QC5-enabled all compounds from Tables 1 and 2 to be identified, which confirms the criteria used for the successful analysis of passive samplers. The ACFs in both solutions were stored in a refrigerator overnight. The ACFs with the adsorbed compounds were rinsed with UPW and processed as regular samples, with or without the derivatisation step. One blank was processed in the same way as the samples for each sample site in each series. At derivatisation, a by-product estrone-TBDMS was also detected at $t_{\mathrm{R}} 38.4 \mathrm{~min}$ as described in the literature [66] (see Section 3.3).

Table 2. Composition of control solution QC5 and results of the analysis for the derivatisation procedure.

\begin{tabular}{ccccc}
\hline Compound & CAS NO & $\boldsymbol{t}_{\boldsymbol{r}}, \mathbf{m i n}$ & $\begin{array}{c}\mathrm{m} / \boldsymbol{z} \\
(\mathbf{Q V N} / \mathbf{Q L N})\end{array}$ & $\begin{array}{c}\text { Intensity Estimate } \\
(\mathbf{1 - 5 )})\end{array}$ \\
\hline 4-t-octylfenol-TBDMS & $140-66-9$ & 16.1 & $249 / 32,073$ & 3 \\
4-nonylphenol-TBDMS & $104-40-5$ & 21.6 & $277 / 334,165$ & 2 \\
diclofenac-TBDMS & $15307-86-5$ & 30.2 & $352 / 21,475$ & 2 \\
17beta-estradiol-TBDMS * & $50-28-2$ & 38.8 & $329 / 386,163$ & 2 \\
17alfa-etinylestradiol-TBDMS * & $57-63-6$ & 39.8 & $353 / 410,327$ & 2 \\
\hline
\end{tabular}

* Notation: $m / z$-mass-to-charge ratio; $\mathrm{QVN}-m / z$, which was used to calculate areas for A/AIS ratios; $\mathrm{QLN} \_m / z$, which were used to confirm identity; CAS NO—chemical abstract service number.

In each series, an additional solvent blank $(2 \mathrm{~mL}$ of DCM concentrated in the same way as the sample extracts) was analysed. In the chromatographic run, sample extracts, blanks, pure DCM, and control solutions with typical organic contaminants, respectively, were analysed. The results for the samples were substituted with those for the blanks.

\subsection{Validation of Method}

A cleaning procedure for $\mathrm{ACFs}$ was developed to preserve the original adsorption properties of ACFs after efficient cleaning. Adsorption properties were tested sensorially by shaking tetrahydrothiophene (a characteristically strong odour) and uranine (a characteristi- 
cally strong colour) solutions with the cleaned original ACFs. The same adsorption properties of tetrahydrothiophene and uranine on ACFs were observed using this cleaning procedure.

We followed the validation guidelines for qualitative analytical methods [30]. To this end, we performed repeatability experiments for extracts and blank ACFs. Positive identifications together with the observed intensities from passive samplers were compared with the results from the quantitative method used for grab samples [67] in order to determine cut-off concentrations for the target group of compounds. Cut-off concentrations were determined by establishing false positive and false negative rates at ange of values above and below the expected cut-off concentration. The cut-off limit marks the point at which false negative rates for concentrations above the limit are low [30]. Comparisons of the ratios of peak compound areas to caffeine-D10 were also possible with concentrations in grab samples collected at different times from the same research well for sampling points with relatively stable organic pollution.

\subsection{Data Sets of Presented Examples}

To test the usability and reliability of ACF passive samplers, we collected two sets of data to show three usability examples. The first refers to a set of data from various aquifers from the entire territory of Slovenia and the second refers to the pilot area of the Ljubljansko polje aquifer.

Slovenia: With an area of $20,273 \mathrm{~km}^{2}$, Slovenia ranks as a medium-sized European country. In Europe, Slovenia is among the countries with the most abundant groundwater resources. Its groundwater is located in aquifers with granular, fissured, and karstic porosity. The efficacy of the ACF method was tested on 470 groundwater samples from all over Slovenia in the period 2013-2019.

Ljubljansko polje aquifer: An aquifer of intergranular porosity consisting of the deposits of the Sava River. In some places, the deposits lie deeper than $100 \mathrm{~m}$ [68,69]. For the most part, the aquifer is open; in some areas less permeable layers appear. The hydraulic permeability of the aquifer layer is high, ranging from $1.2 \times 10^{-2} \mathrm{~m} / \mathrm{s}$ in the central part of the field to $3.7 \times 10^{-3} \mathrm{~m} / \mathrm{s}$ at the edge of the field [70]. The experimentally determined groundwater flow velocity is estimated at $25 \mathrm{~m} /$ day, but it is also estimated that the groundwater velocity in the area ranges from a few metres to a few tens of metres per day. The groundwater generally flows parallel to the Sava River, from west to east. The aquifer is mainly recharged by two components: the Sava River and infiltrating precipitation [71]. The catchment area is subjected to a variety of human activities that affect the quality of the groundwater.

The sampling design network used for testing the method covered the entire Ljubljansko polje aquifer area (Figure 2). Passive sampling devices were installed in 13 observation wells in the saturated zone where contact with groundwater was constant. The exposure time of each passive sampler was 3 months. In case No. 2 (described in Section 3.6.2), a total of 47 samples were collected across five campaigns during the period 2012-2017. The data for case No. 3 (Section 3.6.3.) were obtained for both passive and point samples over the period from March to November 2015. Field parameters were also measured at the same time. During the sampling period, the temperature values varied between 7.00 and $14.04{ }^{\circ} \mathrm{C}$, the $\mathrm{pH}$ electrical conductivity (at $20^{\circ} \mathrm{C}$ ) ranged from 326 to $838 \mu \mathrm{s} / \mathrm{cm}$, the $\mathrm{pH}$ of water samples ranged from 7.2 to 7.8 , and the total organic carbon (TOC) ranged from 0.20 to $0.61 \mathrm{mg} / \mathrm{L}$ during the exposure of passive samples in groundwater. 


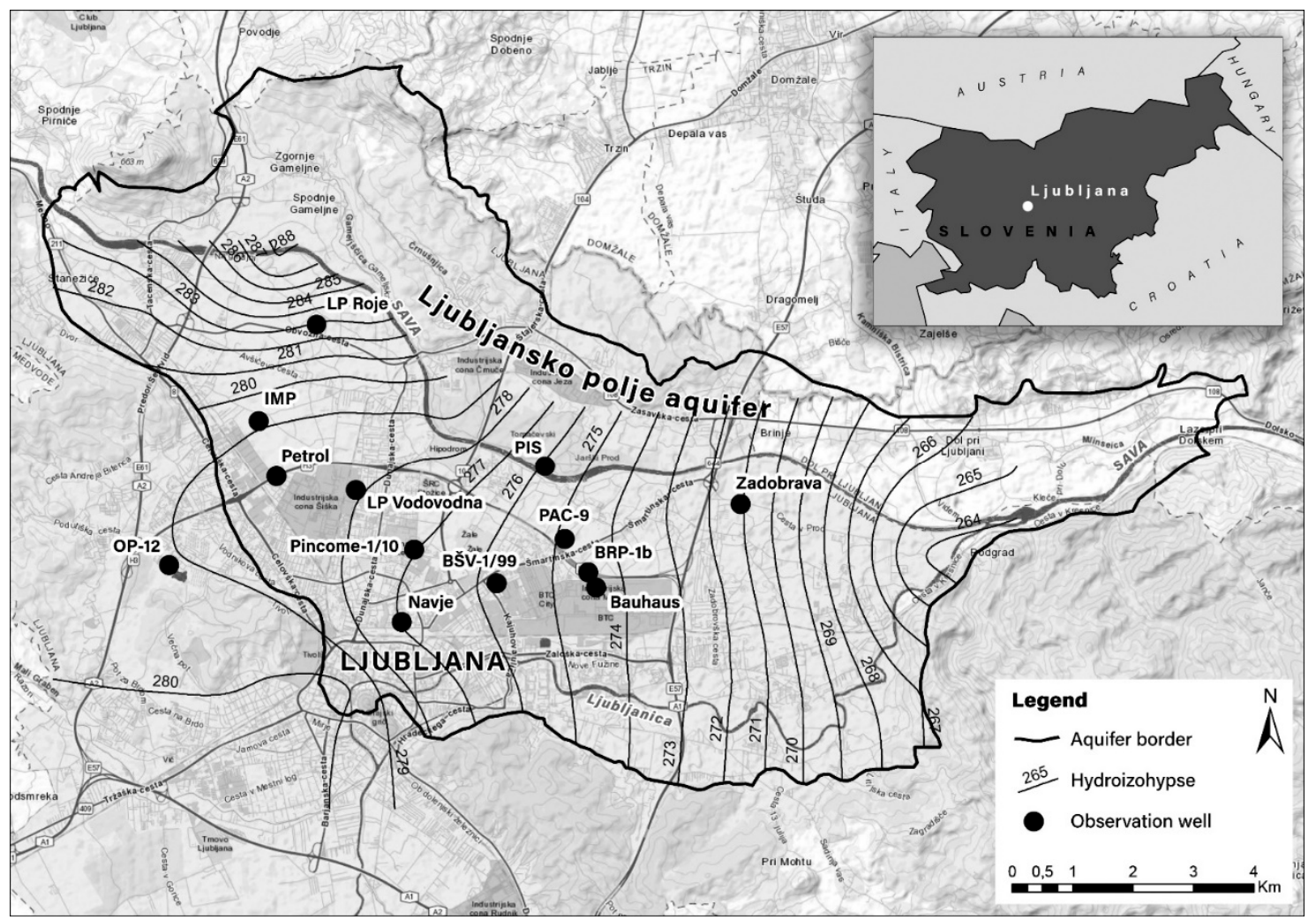

Figure 2. Case study area (Slovenia, Ljubljansko polje aquifer) and site for identification of exposure times (P-1); water table from August 2016.

\section{Results}

\subsection{Design and Use of ACF Passive Samplers in Groundwater}

For years, monitoring of pollutants in groundwater has been conducted through the use of various passive sampling devices. We designed a simple AFC-based passive sampler designed to fit into boreholes in order to determine the extent of organic contamination in groundwater, including contamination from pharmaceuticals and personal care products. Passive sampler devices are easy to install and fit comfortably into boreholes. This design has many advantages over the polar organic chemical integrative sampler, which has no polyethersulphone diffusion membrane overlying the receiving phase [17]. Some studies have reported that more hydrophobic compounds can be retained in the polyethersulfone membrane, as they cannot reach the sorbent layer and consequently remain detected in subsequent analytical screening procedures [8]. In the method presented, there is no absorption of analytes at the membrane. The design is simple and inexpensive, and the number of passive samplers installed is therefore not limited by cost considerations. This allows for parallel sampling at different aquifer depths. The design of the passive samplers allows for good lateral flow of the groundwater in the borehole. Optimal exposure time was evaluated in typical boreholes with the presence of different contaminants. Based on a comparison of peak abundances for the detected compounds after different exposure times (from 14 days to 6 months), an exposure time of three months was chosen. The selected exposure time was also tested at heavily polluted boreholes to check for possible replacement of more loosely bound compounds with compounds with a higher tendency for adsorption on ACFs (see Section 3.4).

Three months after the installation, all passive samplers remained in place undisturbed and without excess replacement of the more loosely bound compounds with compounds with a stronger affinity for AFC, even in heavily polluted groundwater (see Section 3.4). 


\subsection{Optimisation of Purification, Elution, and Desorption Procedure from Active Carbon Fibres}

In the course of developing the method, we evaluated two different methods of ACF purification. The first consisted of purification in a Binder VD-23 vacuum drying oven at $200{ }^{\circ} \mathrm{C}$, and the second involved purification in a Binder FP-115 drying oven at $300{ }^{\circ} \mathrm{C}$. Vacuum purification at $200{ }^{\circ} \mathrm{C}$ was not effective due to the slow purification process and the presence of background compounds from the oven. Heating the ACFs in a conventional drying oven produced the best results, which is why this procedure was used in our further work. The ACFs were re-activated using a few drops of UPW to generate steam before filling the vial with UPW.

The elution of the adsorbed substances was performed using the following two eluents dichloromethane (DCM) and DCM with 5\% MeOH. Figure 3 shows a comparison of the two methods. In the elution processes, the more polar substances (e.g., 1-methyl$1 \mathrm{H}$-benzotriazole, propyphenazone, carbamazepine) showed better elution. DCM with $5 \% \mathrm{MeOH}$ provided better elution of polar compounds from ACFs at the $\mathrm{MeOH}$ level, which did not interfere with the determination of volatiles and non-polar compounds (e.g., benzene), which were successfully eluted from ACFs using the second approach (DCM with $5 \% \mathrm{MeOH}$ ) (Figure 3).

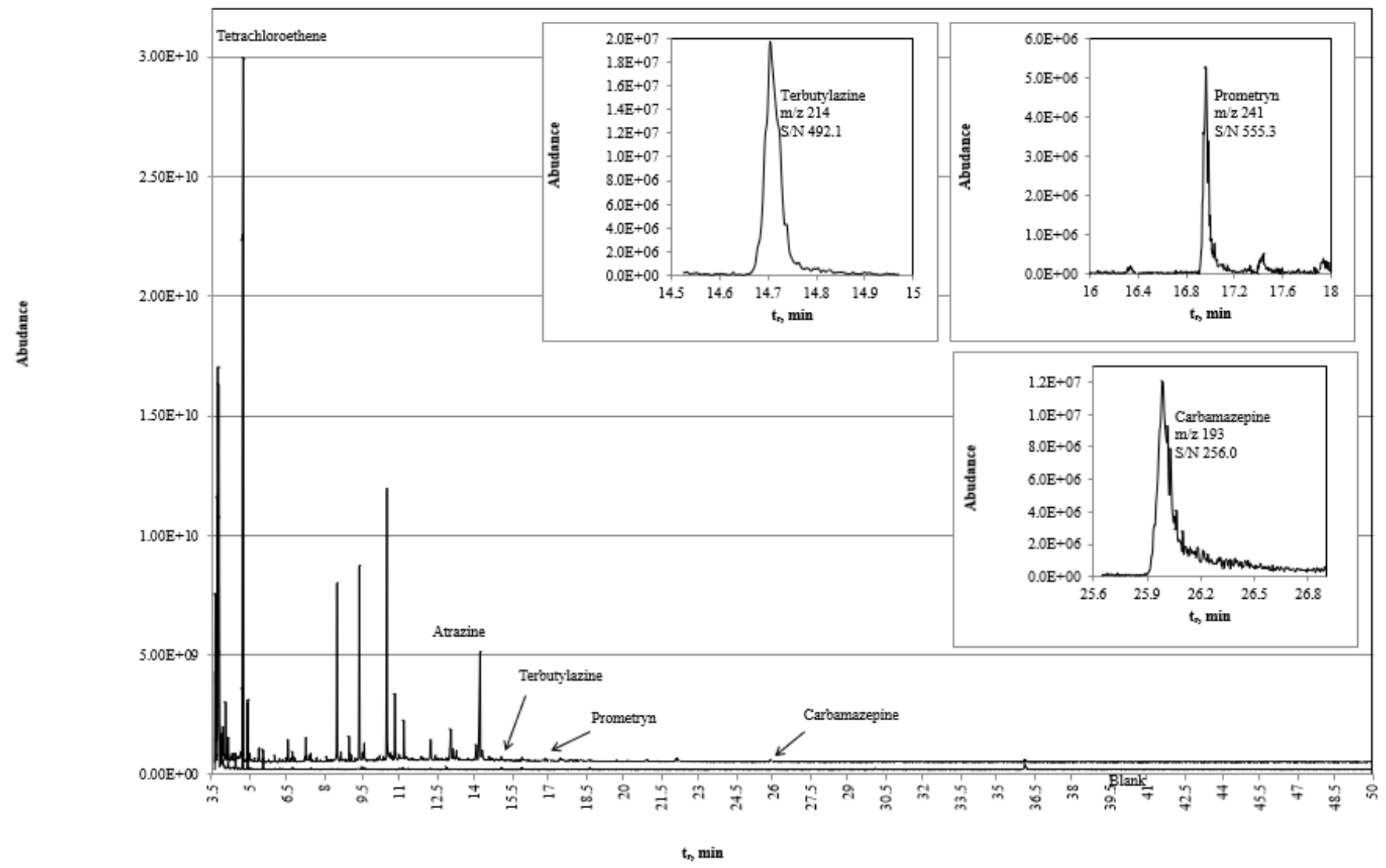

Figure 3. Comparison of elution efficiency of QC4 from ACFs using the two different methods (DCM (below) and DCM with 5\% $\mathrm{MeOH}$ (above)).

\subsection{Confirmation of Non-Targeted Screening}

In order to confirm the repeatability of the method, experiments were performed for six extracts with $5 \mu \mathrm{L}$ spiking solution (Tables 1 and 2-with derivatisation), at approx. $100-1000 \mathrm{mg} / \mathrm{L}$ in $20 \mathrm{~mL}$ of UPW. A QC4 solution was used as a control of the extraction procedure. A QC5 solution was used as a control for the extraction procedure with the derivatisation step. At the same time, six blank ACFs were analysed. Results from the analysis of the regular QC samples and the blanks were collected to test reproducibility. 
Table 1 presents the results of the analysis with the QC4 solution. The results show that a whole range of compounds can be identified, from volatile compounds, e.g., benzene, to less volatile ones, e.g., estrone.

Derivatisation was performed directly from the ACFs with the addition of MTBASTFA with $1 \%$ t-BDMCS, followed by the dissolution of the derivatised extract in an extraction solvent. The results of the analysis of the QC5 solution show that many compounds, including steroid-based hormones, can be identified (Table 2, Figure 4).

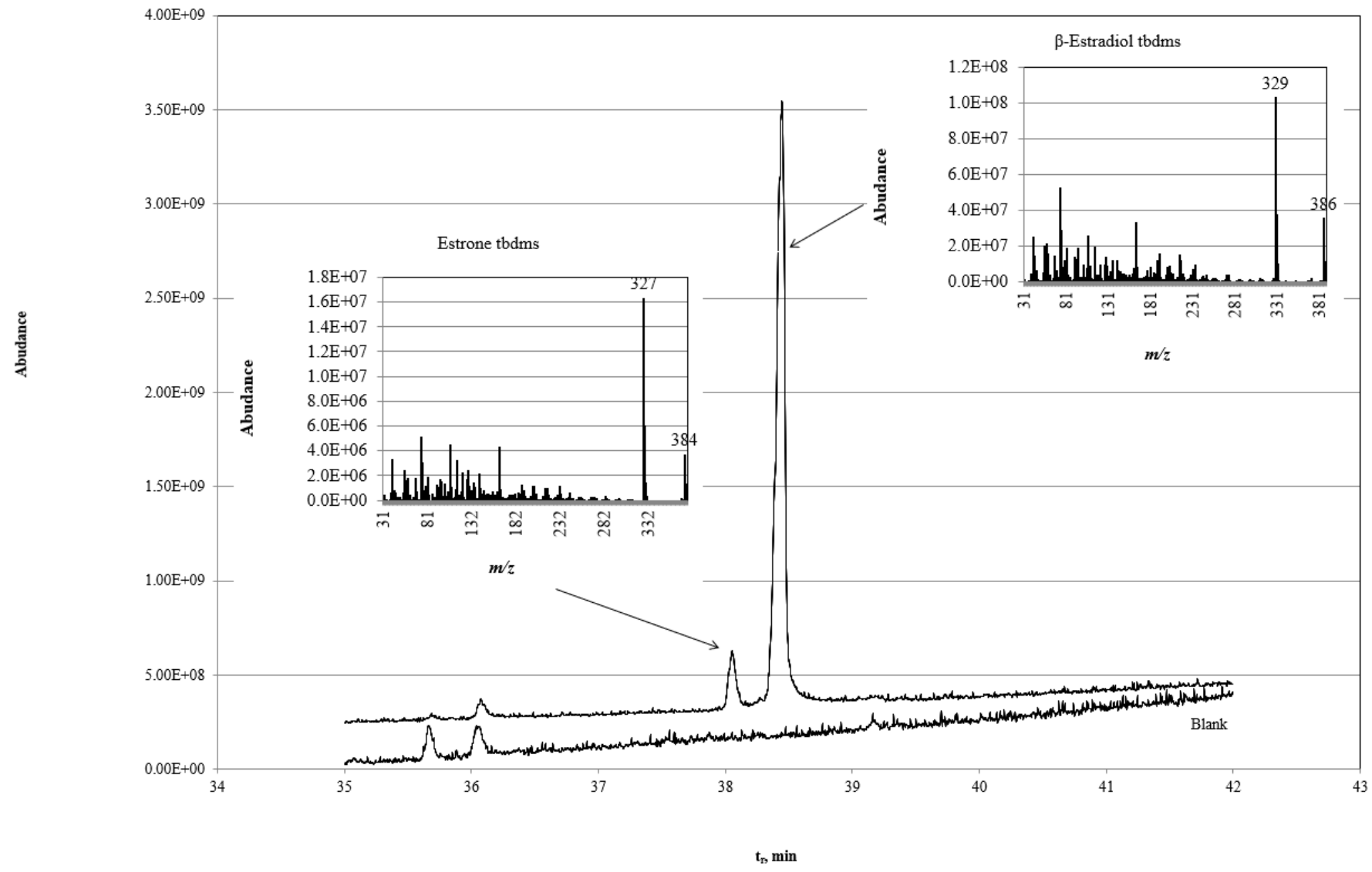

Figure 4. TIC ( $m / z$ 30-750) GC-MS chromatogram of extract from ACFs with adsorbed app. $0.5 \mu \mathrm{g}$ 17beta-estradiol and blank ACFs after derivatisation.

\subsection{Influence of Exposure Time in Highly Polluted Groundwater}

The influence of exposure time was investigated for five compounds detected in heavily polluted groundwater. A test for the possible replacement of the more loosely bound compounds by more firmly bound compounds was carried out at the heavily polluted DBP-5 site (Figure 2) with concentrations for most organic pollutants below the detection limit of quantitative analyses (Table 3). The test was conducted in the period between April and August 2017 at the selected borehole, where five passive samplers were installed at the same depth at the same time. One passive sampler was transferred to the laboratory after 14, 28, 58, 95, and 120 days of exposure, respectively. Figure 5 shows the chromatogram area ratios of prometryn, terbutryn, carbamazepine, propyphenazone, and 1,4-dioxane against caffeine-D10 at different times of passive sampler exposure. Despite the possible effect of displacement of certain compounds due to more strongly adsorbed compounds after three months of exposure, the ACFs are still in kinetic mode for most compounds, even in heavily polluted groundwater. Therefore, an exposure time of three months was chosen. Only volatile 1,4-dioxane showed some desorption effect, but the compound was still detectable even after four months of exposure. Field measurements during the determination of passive sample exposure times are presented in Table 3. 
Table 3. Selected analysis results for grab samples collected at the highly polluted sampling site DBP-5 used to test the influence of exposure time.

\begin{tabular}{ccccc}
\hline Parameter/Date & 28 February 2017 & 21 March 2017 & 6 April 2017 & Unit \\
\hline Temperature (on field) & 11.4 & 10.8 & 10.7 & ${ }^{\circ} \mathrm{C}$ \\
Electroconductivity $\left(20^{\circ} \mathrm{C}\right)$ & 658 & 630 & 676 & $\mu \mathrm{S} / \mathrm{cm}$ \\
Dissolved oxygen & - & 0.12 & 0.12 & $\mathrm{mg} / \mathrm{L}$ \\
Total organic carbon & 9.67 & 10.27 & 9.76 & $\mathrm{mg} / \mathrm{L}$ \\
Ammonium & 7.9 & 7.4 & 7.9 & $\mathrm{mg} / \mathrm{L}$ \\
Nitrate & $<0.2$ & - & $<0.2$ & $\mathrm{mg} / \mathrm{L}$ \\
Chloride & 28.9 & - & 28.6 & $\mathrm{mg} / \mathrm{L}$ \\
Hydrogencarbonate & 431 & - & 434 & $\mathrm{mg} / \mathrm{L}$ \\
Iron, dissolved & - & 3.03 & 2.91 & $\mathrm{mg} / \mathrm{L}$ \\
Terbutryn & 2.25 & 2.73 & - & $\mu \mathrm{g} / \mathrm{L}$ \\
Propyphenazone & 0.072 & 0.087 & - & $\mu \mathrm{g} / \mathrm{L}$ \\
Prometryn & 0.11 & $<\mathrm{LOD}=0.0020$ & - & $\mathrm{\mu g} / \mathrm{L}$ \\
Carbamazepine & 0.36 & 0.35 & - & $\mathrm{\mu g} / \mathrm{L}$ \\
\hline
\end{tabular}

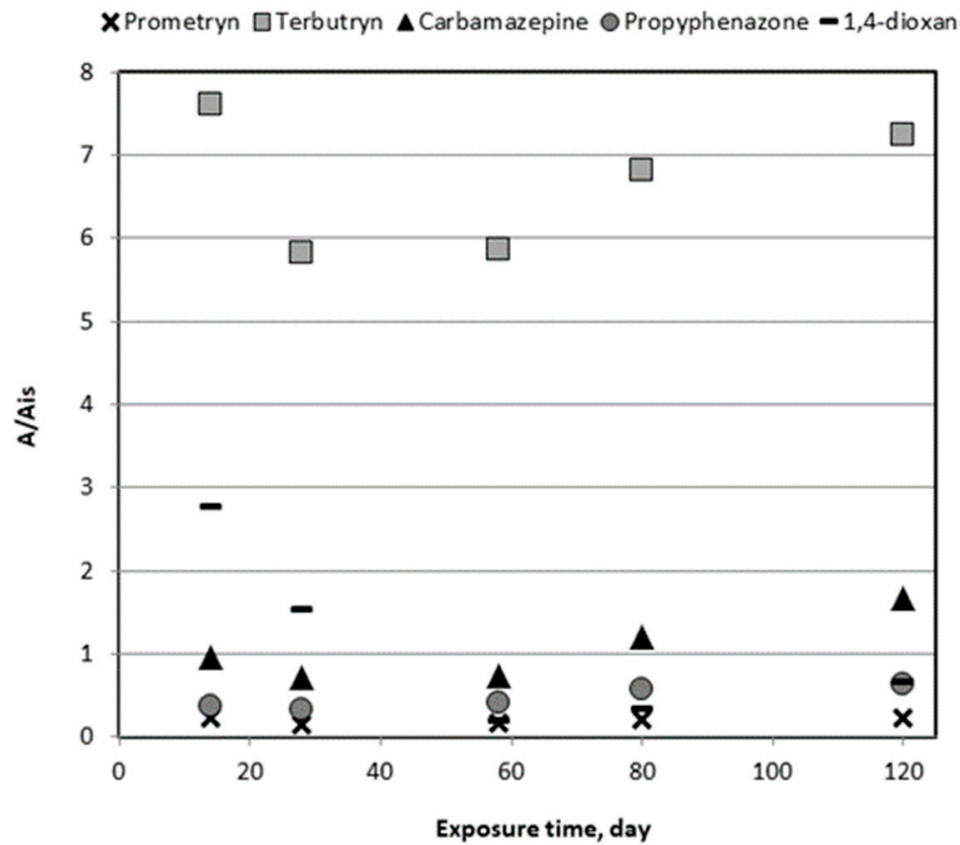

Figure 5. Chromatogram area ratios between selected compounds and the internal standard caffeineD10 for different exposure times of passive samplers in highly polluted groundwater.

\subsection{Validation on Synthetic Samples}

For validation of repeatability, experiments were conducted for extracts of six spiking solutions with (Table 1) and without derivatisation (Table 2). In parallel, six blank ACFs were analysed. In Table 1, repeatability results for the experiments using the QC4 solution, together with the six blanks, are presented. The expected compounds were identified by GC-MS TIC in all cases. The compounds of the QC4 solution were not detected in the blanks that were processed at the same time. The only compound detected in the blanks was benzene (maximal detected area in six blanks was $5.9 \%$ of the average area value for benzene from six samples of QC4 solution). The repeatability experiments (Table 1) showed that the loss of volatiles (e.g., benzene) during the drying step is negligible. Results of the analysis of regular QC samples and blanks showed occasional extract contamination by volatiles, mostly from BTEX (benzene, toluene, ethylbenzene, and xylenes). The main source of BTEX is air pollution from automotive traffic [72]. Pollution can occur during the time of preparation of ACFs, installation at the sampling point, transport, elution of compounds, or during the operation step of gas chromatography. Purity checks for the prepared ACFs were 
performed before installation. The blanks were analysed for each series; any similar levels of the compound discovered in the blanks were not reported. Derivatisation without additional manipulation of the samples was performed for polar analytes.

\subsection{Applicability of the AFC Method in Groundwater Quality Studies}

As mentioned earlier, the applicability of the developed method was tested in hydrogeological studies. Three examples are presented below.

\subsubsection{Example 1-Non-Targeted Qualitative Screening}

In order to demonstrate the efficacy of the method, a dataset of organic compounds in groundwater determined by the AFC method was analysed. Overall, 470 groundwater samples were collected between 2013 and 2019 throughout the territory of Slovenia. All extracts from the passive samplers were analysed by GC-MS, as described in the Materials and Methods chapter. During the monitoring period, a total of 892 compounds were detected using ACF passive samplers. A list of the contaminants detected in groundwater is shown in the results and Supplementary Materials (Table S1). The list indicates that the method allows for the detection of a wide range of compounds. Some of the compounds were detected using a comparison with pure reference substances, while others were detected at a tentative level. Retention times and mass spectra of the compounds in the sample extracts were used to identify the compounds present. In addition, experimental product ions were matched with commercial databases for mass spectra. The value of the historical data will be appreciated in the long run, as they can be used as comparative results in future studies on changes in the extent and rate of potential groundwater pollution in Slovenia.

\subsubsection{Example 2-Identifying the Presence and Source of Organic Compounds} in Groundwater

The Ljubljansko polje aquifer is a highly important source of drinking water supply. Various human activities are carried out on the ground above, all of which affect the quality of the groundwater below the surface. The aim of the present monitoring action was to determine the presence and source of organic compounds in the aquifer.

Of all of the compounds identified over the course of all five sampling campaigns over the period of 6 years, 28 compounds detected more than eight times were selected for a more detailed analysis (Table 4). For individual compounds, each group was categorised according to type, typical use, and likely source. The following six groups of organic compounds were determined based on the type of source: "Halogenated Solvents", "Non-halogenated Solvents", "Pesticides", "Domestic and Personal Compounds", "Plasticisers and Additives", and "Other Industrial Compounds" [15-65]. An evaluation of three different groups of pollutants according to their origin (urban, agricultural, and industrial pollution) was then performed [15]. Pesticides were classified as "Agricultural Use Compounds." Compounds in the groups "Domestic and Personal Compounds" and "Other Industrial Compounds" were classified as "Urban Use Compounds". "Halogenated Solvents", "Non-halogenated Solvents", and "Plasticisers and Additives" were categorised as "Industrial Use Compounds".

In addition to tetrachloroethene and trichloroethylene, pesticides were the most commonly detected compounds (Figure 6). Atrazine (91\% of the samples) was also prevalent in multi-component mixtures, although its use had been banned since 2004 [73]. Such as atrazine, simazine (55.3\%), and propazine (38.3\%), which were also detected (Figure 6), have been banned from use in the EU since 2004 [73]. This may indicate either its persistence in groundwater, which is more likely, or illegal use. Terbuthylazine (31.9\%) and its metabolite desethyl-terbuthylazine (51.1\%) were also detected in groundwater. The use of terbuthylazine has replaced atrazine in Slovenia, where it is used together with metolachlor to control weeds in corn fields. Among the urban compounds, 2,4-dimethyl-2H-benzotriazole (51\%) and 2-methyl-2H-benzotriazole (47\%) were most frequently detected in the samples. Typical 
domestic- and personal-use compounds were found to occur in less than a quarter of all samples $(<23 \%)$.

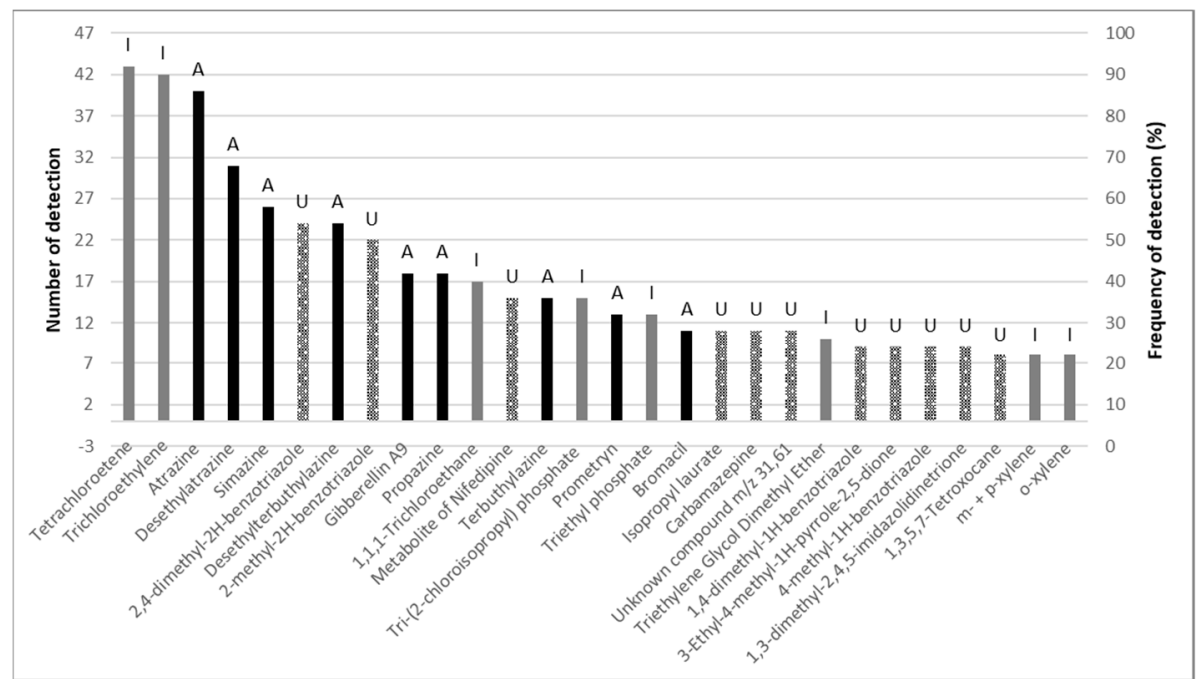

Figure 6. Frequency of selected organic compounds in groundwater based on the type of source (I-industrial, A-agricultural, and U-urban).

The analysis of the compounds by type and typical use shows that pesticides were the most commonly detected compounds (40\%), followed by halogenated solvents (21\%), (Figure 7). Domestic and personal use compounds were detected at a rate of $15 \%$, with other groups following in smaller proportions. Looking at the groups of compounds according to their origin (Table 4), the most frequently detected compounds are agricultural in origin $(40 \%)$, followed by compounds of industrial and urban origin ( $32 \%$ and $28 \%$ ) (Table 5).

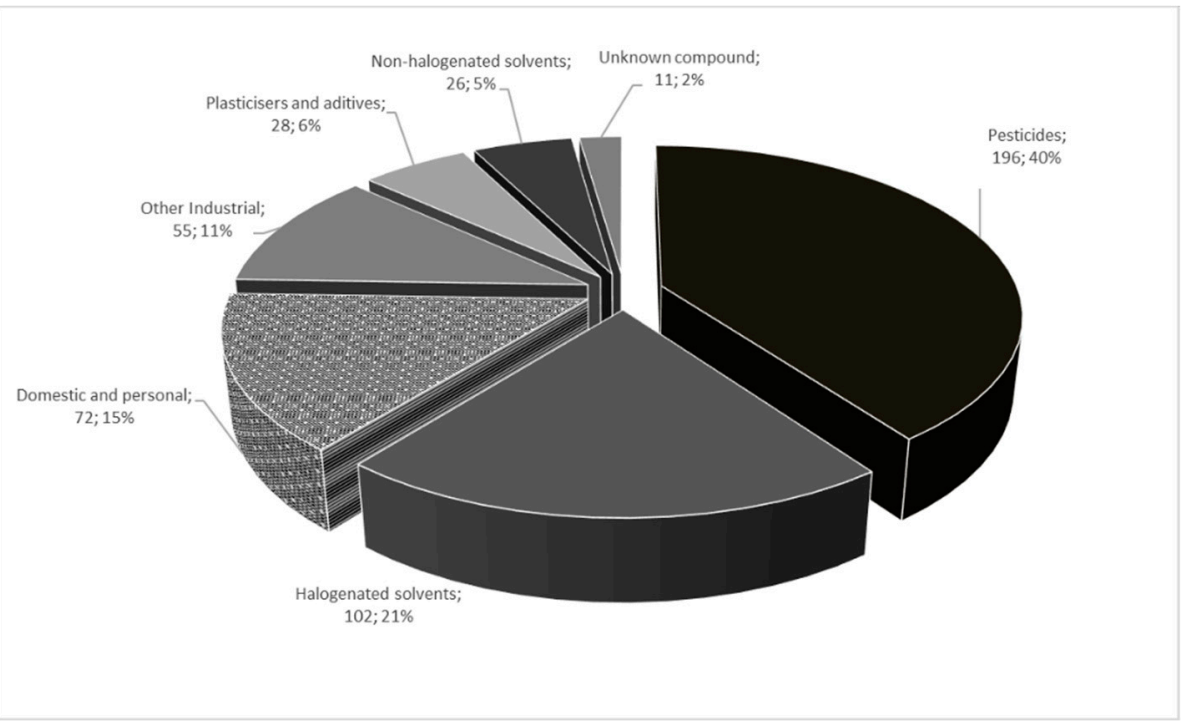

Figure 7. Identification frequency of compounds according to type and typical use. 
Table 4. List of selected organic compounds in groundwater, sources, and typical use.

\begin{tabular}{|c|c|c|c|c|c|c|c|}
\hline CAS NO & $t_{r}(\min )$ & Substance & Source & Group & Use & Nr. of Detection & $\%$ of Detection \\
\hline $127-18-4$ & 4.5 & Tetrachloroetene (c.i.) & $\begin{array}{c}\text { Dry cleaning, solvent, degreasing in the metal } \\
\text { industry }\end{array}$ & Halogenated solvents & I & 43 & 91.5 \\
\hline $79-01-6$ & 3.8 & Trichloroethylene (t.i.) & $\begin{array}{c}\text { Dry cleaning, solvent, degreasing in the metal } \\
\text { industry }\end{array}$ & Halogenated solvents & I & 42 & 89.4 \\
\hline $1912-24-9$ & 14.2 & Atrazine (c.i.) & Herbicide & Pesticide & A & 40 & 85.1 \\
\hline $6190-65-4$ & 13 & Desethylatrazine (c.i.) & Atrazine degradation product & Pesticide & A & 31 & 66.0 \\
\hline $122-34-9$ & 14.1 & Simazine (t.i.) & Herbicide & Pesticide & A & 26 & 55.3 \\
\hline- & 9.4 & $\begin{array}{c}\text { 2,4-dimethyl-2H- } \\
\text { benzotriazole } \\
\text { (t.i.) }\end{array}$ & $\begin{array}{l}\text { Degradation of corrosion inhibitors e.g. } \\
\text { 4-methyl-1H-benzotriazole }\end{array}$ & Other Industrial & $\mathrm{U}$ & 24 & 51.1 \\
\hline $30125-63-4$ & 13.2 & Desethylterbuthylazine (c.i.) & Terbuthylazine degradation product & Pesticide & A & 24 & 51.1 \\
\hline $16584-00-2$ & 8.5 & $\begin{array}{l}\text { 2-methyl-2H-benzotriazole } \\
\text { (c.i.) }\end{array}$ & $\begin{array}{c}\text { Degradation of corrosion inhibitors e.g. } \\
1 \mathrm{H} \text {-benzotriazole }\end{array}$ & Other Industrial & $\mathrm{U}$ & 22 & 46.8 \\
\hline $427-77-0$ & 20.8 & Gibberellin A9 (t.i.) & Natural fungicide & Pesticide & A & 18 & 38.3 \\
\hline $139-40-2$ & 14.3 & Propazine (c.i.) & Herbicide & Pesticide & A & 18 & 38.3 \\
\hline $71-55-6$ & 3.6 & 1,1,1-Trichloroethane (t.i.) & Solvent & Halogenated solvents & I & 17 & 36.2 \\
\hline $99982-48-6$ & 24.7 & $\begin{array}{l}\text { Metabolite of Nifedipine } \\
\text { (t.i.) }\end{array}$ & From drug nifedipine & $\begin{array}{l}\text { Domestic and } \\
\text { personal }\end{array}$ & $\mathrm{U}$ & 15 & 31.9 \\
\hline 7287-19-6 & 16.9 & Prometryn (c.i.) & Herbicide & Pesticide & A & 13 & 27.7 \\
\hline $78-40-0$ & 7.6 & Triethyl phosphate (t.i.) & Plasticizers & $\begin{array}{l}\text { Plasticisers and } \\
\text { aditives }\end{array}$ & I & 13 & 27.7 \\
\hline $314-40-9$ & 17.5 & Bromacil (t.i.) & Herbicide & Pesticide & A & 11 & 23.4 \\
\hline $10233-13-3$ & 12.5 & Isopropyl laurate (t.i.) & Natural compound, cosmetics & $\begin{array}{l}\text { Domestic and } \\
\text { personal }\end{array}$ & $\mathrm{U}$ & 11 & 23.4 \\
\hline $298-46-4$ & 26 & Carbamazepine (c.i.) & Drug & $\begin{array}{l}\text { Domestic and } \\
\text { personal }\end{array}$ & $\mathrm{U}$ & 11 & 23.4 \\
\hline- & 5.4 & $\begin{array}{l}\text { Unknown compound } \mathrm{m} / \mathrm{z} \\
31,61 \text { (t.i.) }\end{array}$ & - & - & $\mathrm{U}$ & 11 & 23.4 \\
\hline $112-49-2$ & 8.8 & $\begin{array}{l}\text { Triethylene Glycol Dimethyl } \\
\text { Ether (t.i.) }\end{array}$ & Solvent & $\begin{array}{l}\text { Non-halogenated } \\
\text { solvents }\end{array}$ & I & 10 & 21.3 \\
\hline
\end{tabular}


Table 4. Cont.

\begin{tabular}{|c|c|c|c|c|c|c|c|}
\hline CAS NO & $t_{r}(\min )$ & Substance & Source & Group & Use & Nr. of Detection & $\%$ of Detection \\
\hline- & 10.8 & $\begin{array}{l}\text { 1,4-dimethyl-1H- } \\
\text { benzotriazole } \\
\text { (t.i.) }\end{array}$ & $\begin{array}{l}\text { In connection with } \\
\text { 2,4-dimethyl-2H-benzotriazole }\end{array}$ & Other Industrial & $\mathrm{U}$ & 9 & 19.1 \\
\hline $20189-42-8$ & 8.8 & $\begin{array}{l}\text { 3-Ethyl-4-methyl-1H- } \\
\text { pyrrole-2,5-dione } \\
\text { (t.i.) }\end{array}$ & $\begin{array}{l}\text { Natural compound, green tea, pyrolysis of } \\
\text { natural materials, waste water }\end{array}$ & $\begin{array}{l}\text { Domestic and } \\
\text { personal }\end{array}$ & $\mathrm{U}$ & 9 & 19.1 \\
\hline 29878-31-7 & 11.7 & $\begin{array}{l}\text { 4-methyl-1H-benzotriazole } \\
\text { (t.i.) }\end{array}$ & Corrosion inhibitor, tolytriazole & $\begin{array}{l}\text { Domestic and } \\
\text { personal }\end{array}$ & $\mathrm{U}$ & 9 & 19.1 \\
\hline $293-30-1$ & 8.6 & 1,3,5,7-Tetroxocane (t.i.) & Formaldehide derivative & $\begin{array}{l}\text { Domestic and } \\
\text { personal }\end{array}$ & $\mathrm{U}$ & 8 & 17.0 \\
\hline $108-38-3$ & 5.3 & m- + p-xylene (c.i.) & Automotive, solvent & $\begin{array}{l}\text { Non-halogenated } \\
\text { solvents }\end{array}$ & I & 8 & 17.0 \\
\hline $95-47-6$ & 5.4 & o-xylene (c.i.) & Automotive, solvent & $\begin{array}{l}\text { Non-halogenated } \\
\text { solvents }\end{array}$ & I & 8 & 17.0 \\
\hline
\end{tabular}


Table 5. Classification of selected compounds by group according to type, use and origin.

\begin{tabular}{|c|c|c|c|c|}
\hline Type and Group & Source & Use & $n$ & Share $(\%)$ \\
\hline $\begin{array}{l}\text { Halogenated solvents } \\
\text { Non-halogenated solvents } \\
\text { Plasticisers and aditives }\end{array}$ & Industrial compounds & I & 156 & 32 \\
\hline $\begin{array}{c}\text { Domestic and personal } \\
\text { Other Industrial }\end{array}$ & Urban compounds & $\mathrm{U}$ & 138 & 28 \\
\hline Pesticides & Agricultural compounds & A & 196 & 40 \\
\hline
\end{tabular}

This example shows how we can interpret passive sampling data related to groundwater quality and possible pressures from different pollution sources.

\subsubsection{Example 3-Comparison of the Passive Sampling Method with the Grab Samples}

In the same research area, on the Ljubljana aquifer, the results of passive sampling were compared with data obtained from grab sampling at all thirteen sampling points (Figure 8). A comparison was made using existing point sample monitoring data [74]. Contaminant concentrations are low, on average below $1 \mu \mathrm{g} / \mathrm{L}$, and stable. Passive sampling was performed from late-May to early-September 2015. However, grab sampling was performed twice, in March and November 2015. Moreover, spatial distributions from passive samplers were compared to those from the grab sampling procedure for tetrachloroethene, a volatile solvent and a typical pollutant from industrial and urban use (PCE). Figure 8 shows the results for the determination of tetrachloroethene using both methods in the Ljubljansko polje pilot area. The results of grab sampling are given as averages of the two measurements; the results of passive sampling are stated as the ratios As/Ais, where the ratio expresses the relation of peak areas of the compound to caffeine-D10; the results are collected in Table 6. A comparison of their distributions showed a good correlation. Some noticeable differences can be observed at concentrations below the LOD. The results of passive sampling show higher values for the piezometers PIS and LP Roje, located near the Sava River. The phenomenon is very likely the consequence of occasional plumes of tetrachloroethene in the Sava River, a recharge component of the aquifer. This is evidence that integrative sampling is one of the major advantages of passive sampling compared to grab sampling in determining the source and origin of low or early pollution. In particular cases, in accordance with the particular aim of the hydrogeological research, the results of the passive sampling can serve to represent a reliable substitute for grab sampling.

Table 6. Comparison of grab and passive samples in the Ljubljansko polje aquifer.

\begin{tabular}{ccc}
\hline Sampling Point & $\begin{array}{c}\text { Grab Samples }(\mu \mathrm{g} / \mathrm{L}) \\
\text { Tetrachloroethene }\end{array}$ & $\begin{array}{c}\text { Passive Samples (A/Ais) } \\
\text { Tetrachloroethene }\end{array}$ \\
\hline LP Roje & $<$ LOD & 13.83 \\
LP Vodovodna & 0.07 & 3.81 \\
PINCOME-1/10 & 0.52 & 40.84 \\
Bauhaus & 0.97 & 51.94 \\
BRP-1B & 0.70 & 61.44 \\
BŠS-1/99 & 0.35 & 19.89 \\
IMP & 0.37 & 15.85 \\
Navje & 1.10 & 29.62 \\
OP-12 & 0.63 & 41.30 \\
PAC-9 & 0.12 & 4.40 \\
Petrol & $<$ LOD $=0.06$ & 3.09 \\
PIS & $<$ LOD $=0.06$ & 31.30 \\
Zadobrova & 0.66 & 40.27
\end{tabular}


(a)

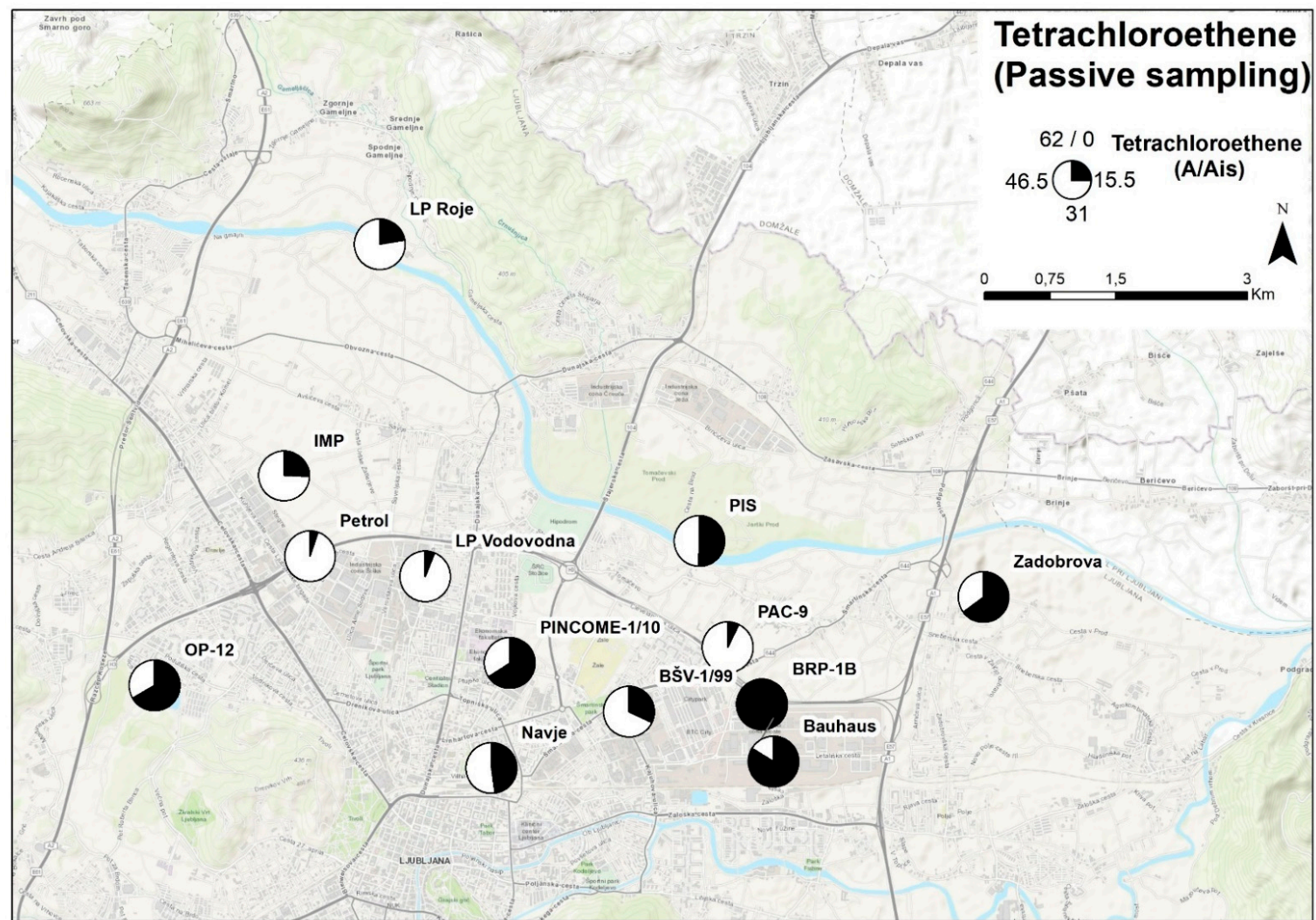

(b)

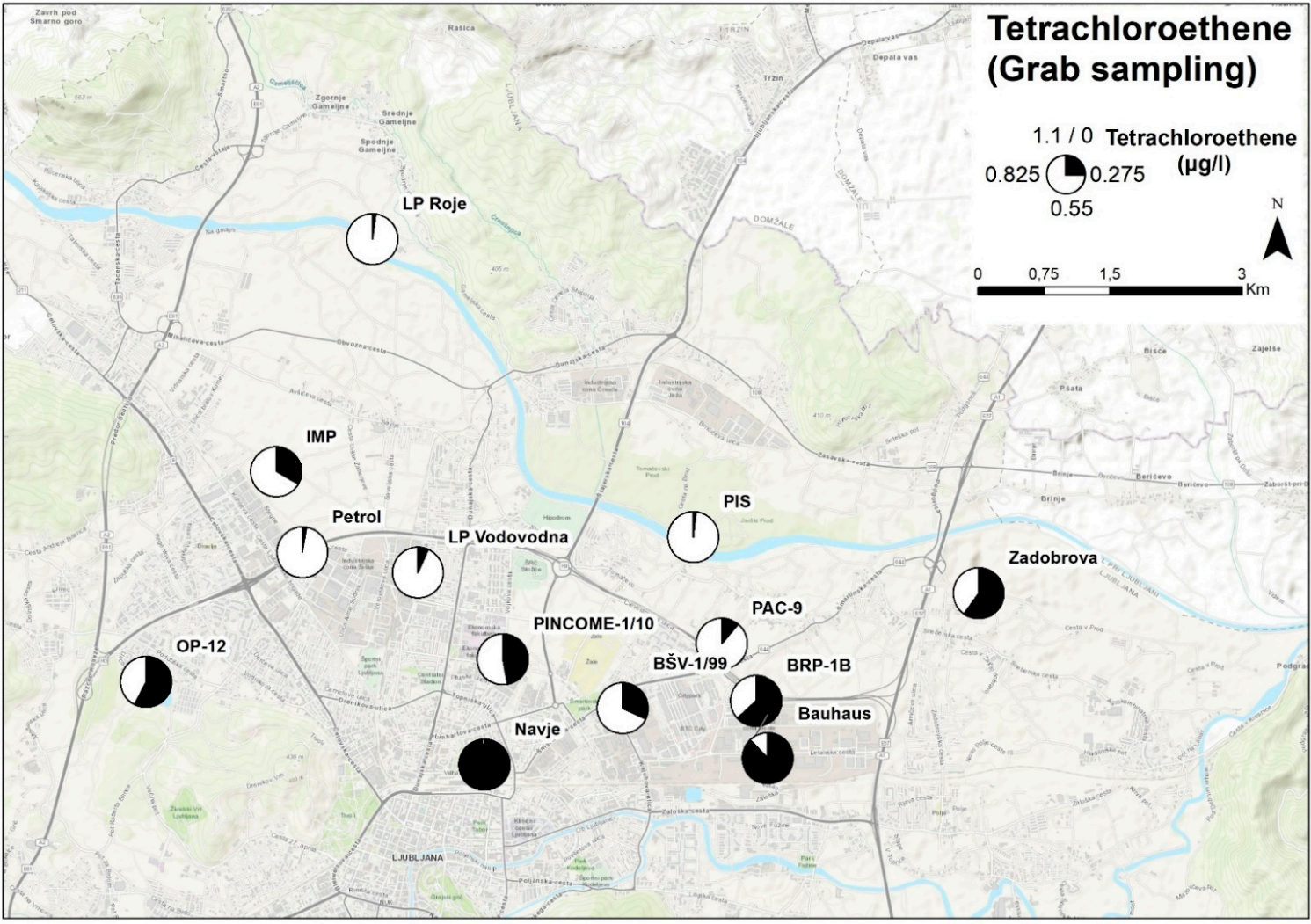

Figure 8. Comparison of results for the distribution of (a) tetrachloroethene between passive and (b) grab sampling at the Ljubljansko polje aquifer in 2015. 
The comparison of samples between passive samplers and samples from quantitative chemical analysis was performed based on normalised values (Figure 9). The averaged results of grab sampling were normalised according to the highest value quantitatively determined in the area (Navje; $1.08 \mu \mathrm{g} / \mathrm{L}$ ). The ratios of As/Ais at the particular site of passive sampling were normalised against the highest ratio (BRP-1,61.4). The comparison of both results shows a good overlapping of results for PCE $\left(\mathrm{R}^{2}=0.53\right)$ and for spatial distribution, confirmed by the spatial comparison of PCE distribution throughout the Ljubljansko polje aquifer (Figure 9). Minor deviations are possible due to the time frame. Passive samplers cover long sampling periods of pollutants in water, while quantitative analysis provides information about the current concentration of pollutants in a given sample.

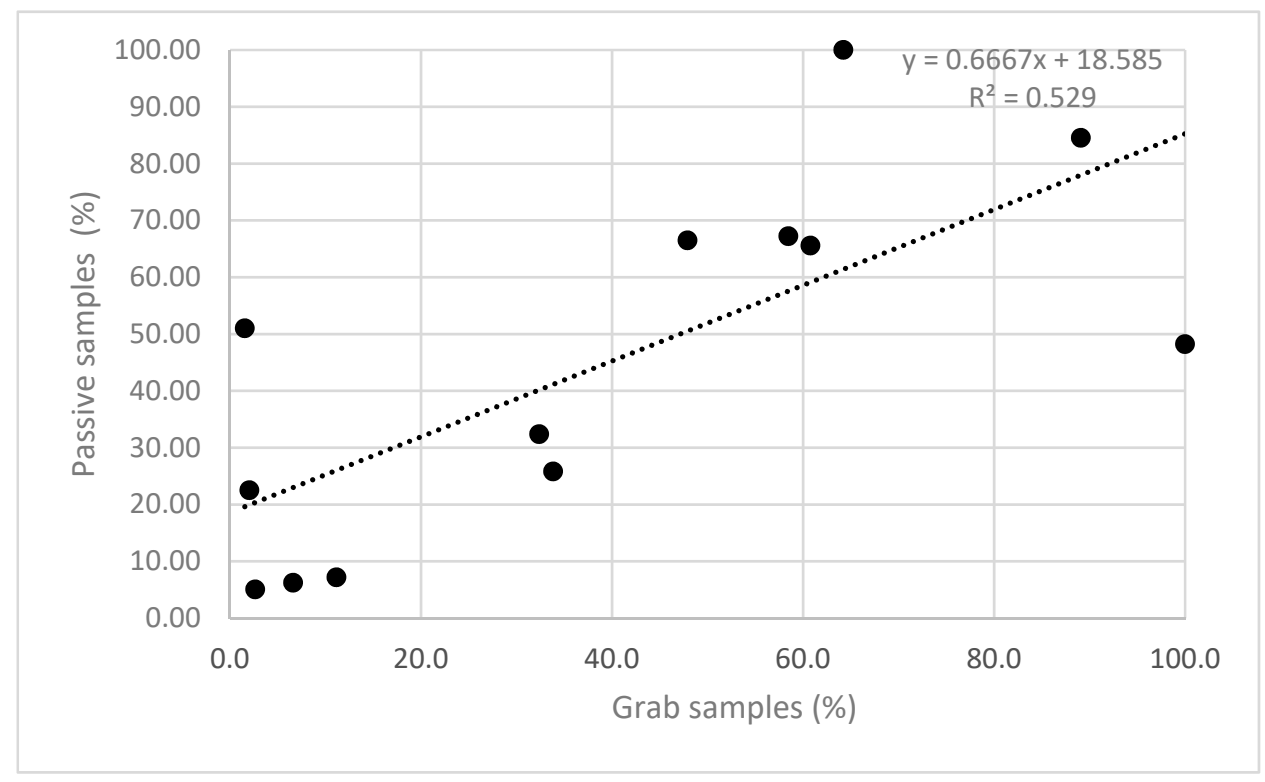

Figure 9. Linear dependence between the quantitative and qualitative determination of PCE.

\section{Discussion}

The purpose of the research was to design a simple passive device based on ACFs with the aim of developing a non-target screening method that would be simple and reasonably repeatable using GC-MS analysis. A stainless steel mesh was used for the casing of the passive sampler. The passive sampler is robust, easy to purify and manipulate, and inexpensive. It enables sampling and analytical quality control and serves to validate the method, confirming the repeatability of the process.

(1) This paper also demonstrates the advantage and applicability of using ACF passive samplers for organic compound screening in groundwater. More organic compounds were detected and identified with ACF passive samplers than through the analysis of grab samples. The sampling method is capable of detecting a wide range of organic compounds unselectively in a single shot.

(2) In the case of groundwater samples from all over Slovenia, 892 organic compounds were detected with ACF passive samplers. It has been proven that this sampling is capable of detecting a wide range of compounds unselectively. In this process, the presence of various organic contaminants in groundwater was identified. Through the use of the AFC sampling technique, we were able to detect a wide range of previously unknown and unspecified compounds in groundwater. This methodology also revealed the presence of transformation products, one of which had not been previously identified at the sampling sites. The results (an extensive list of compounds) are important for the design of different schemes used for monitoring groundwater quality and have the ability to also prioritise the less well-known compounds in groundwater. 
(3) In the case of the Ljubljansko polje aquifer, it has been shown that the identification of organic compounds in groundwater may serve to help assess the risk of potential anthropogenic contamination. This method allows us to detect and evaluate the presence of pollutants and identify their anthropogenic source. From the results of passive sampling, we were able to identify the main compounds and determine their typical use and origin. Depending on the type of compound, we can determine whether the potential contamination of groundwater is agricultural, urban, or industrial in origin.

(4) Parallels between the results of the analysis with passive samplers and the quantitative chemical analysis at the Ljubljansko polje aquifer indicate that the passive sampler method detects the presence of a compound in groundwater already at the level of $\mathrm{pg} / \mathrm{L}$. This means that with the passive sampler method, we are able to detect the presence of very low concentrations of certain compounds in the groundwater that cannot yet be routinely detected using quantitative chemical analyses.

(5) ACF passive samplers are useful for long-term deployments (3 months or more) and for temporal as well as spatial assessments of groundwater concentrations. The effect of the displacement of particular compounds due to more strongly adsorbed compounds was not considered relevant under the circumstances.

(6) A field validation was conducted at sampling sites, and a comparison of samples between passive samplers and samples from quantitative chemical analysis was performed based on normalised values. Results show a good overlapping of results for PCE $(R 2=0.53)$. Spatial comparison of PCE distribution throughout the Ljubljansko polje aquifer also showed minor deviations, which might have occurred due to the difference in the time frame of grab and passive sampling.

(7) The method for groundwater monitoring with passive sampling introduced and optimized herein can be used in a wide range of research projects and monitoring campaigns and is comparable to other passive sampling techniques.

(8) Further investigation of the ACF passive samplers' performance on validation techniques and the evaluation of uncertainty would be appropriate. Moreover, to test for a broader applicability of ACF passive samplers, investigations into their longer deployments under different physicochemical conditions and in additional waters, such as surface and wastewater, would be beneficial.

(9) The method could be very efficient for screening difficult-to-reach areas by interested parties due to the simple field equipment and also undisturbed long-distance transport of samples to the laboratory enabled by the stability of ACFs and the efficient prevention and complete control of possible contamination of samples during their installation and transport. In this case, consideration should be given to the possibility of a trained sampling instructor accessing the sampling site remotely during each sampling.

(10) Last but not least, data collected from groundwater samples obtained using the passive sampling technique could be used for various types of multivariate statistical modelling to identify sources of pollution in the environment. Some studies on the use of passive samplers have already been published in the literature $[17,75]$.

Supplementary Materials: The following supporting information can be downloaded at: https: / / www.mdpi.com/article/10.3390/w14040585/s1; Table S1: List of contaminants detected in groundwater by ACF passive samplers.

Author Contributions: Conceptualisation, P.A. and A.K.; methodology, P.A.; software, P.A. and A.K.; validation, P.A.; formal analysis, P.A.; investigation, P.A.; resources, P.A., A.K., N.M. and B.J.; data curation, P.A., A.K., N.M. and B.J.; writing—original draft preparation, A.K.; writing-review and editing, P.A., A.K., N.M. and B.J.; visualisation, A.K.; supervision, PA.; project administration, B.J.; funding acquisition, P.A., A.K., N.M. and B.J. All authors have read and agreed to the published version of the manuscript.

Funding: This research was funded by JP VOKA SNAGA d.o.o., Ljubljana and in the scope of the Programme Groundwater and Geochemistry (P1-0020) research programme and project “Urban hydrogeology: Improved methods for determining the occurrence, transport processes and origin 
of pharmaceuticals in groundwater resources (Z1-2639)", both financed by the Slovenian Research Agency (ARRS).

Acknowledgments: The authors wish to thank the personnel of JP VOKA SNAGA d.o.o., in particular V.K.Z., K.L. and A.V.

Conflicts of Interest: The authors declare no conflict of interest.

\section{References}

1. Locatelli, M.; Sciasci, F.; Cifelli, R.; Malatesta, L.; Bruni, P.; Croce, F. Analytical methods for the endocrine disruptor compounds determination in environmental water samples. J. Chromatogr. A 2016, 1434, 1-18. [CrossRef]

2. Mirasole, C.; Di Carro, M.; Tanwar, S.; Magi, E. Liquid chromatography-tandem mass spectrometry and passive sampling: Powerful tools for the determination of emerging pollutants in water for human consumption. J. Mass Spectrom. 2016, 51, 814-820. [CrossRef] [PubMed]

3. Vrana, B.; Allan, I.J.; Greenwood, R.; Mills, G.A.; Dominiak, E.; Svensson, K.; Knutsson, J.; Morrison, G. Passive sampling techniques for monitoring pollutants in water. TrAC Trends Anal. Chem. 2005, 24, 845-868. [CrossRef]

4. Allan, I.J.; Harman, C.; Ranneklev, S.B.; Thomas, K.V.; Grung, M. Passive sampling for target and nontarget analyses of moderately polar and nonpolar substances in water. Environ. Toxicol. Chem. 2013, 32, 1718-1726. [CrossRef]

5. Lindholm, P.C.; Knuutinen, J.S.; Ahkola, H.S.J.; Herve, S.H. Analysis of trace pharmaceuticals and related compounds in municipal wastewaters by preconcentration, chromatography, derivatisation, and separation methods. BioResources 2014, 9 , 3688-3732. [CrossRef]

6. Allinson, G.; Allinson, M.; Kadokami, K. Combining passive sampling with a GC-MS-database screening tool to assess trace organic contamination of rivers: A pilot study in Melbourne, Australia. Water Air Soil Pollut. 2015, 226, 230. [CrossRef]

7. Koroša, A.; Auersperger, P.; Mali, N. Determination of micro-organic contaminants in groundwater (Maribor, Slovenia). Sci. Total Environ. 2016, 571, 1419-1431. [CrossRef] [PubMed]

8. Soulier, C.; Coureau, C.; Togola, A. Environmental forensics in groundwater coupling passive sampling and high resolution mass spectrometry for screening. Sci. Total Environ. 2016, 563-564, 845-854. [CrossRef]

9. Auersperger, P.; Lah, K.; Vrbec, A.; Zidar, V.K.; Koroša, A.; Mali, N. Tracing pollutants in groundwater by passive sampling and gas chromatography mass spectrometry. In Proceedings of the 31st International Symposium on Chromatography, ISC-16, Cork, Ireland, 28 August-1 September 2016.

10. Li, Z.; Sobek, A.; Radke, M. Fate of pharmaceuticals and their transformation products in four small european rivers receiving treated wastewater. Environ. Sci. Technol. 2016, 50, 5614-5621. [CrossRef] [PubMed]

11. Booij, K.; Robinson, C.D.; Burgess, R.M.; Mayer, P.; Roberts, C.A.; Ahrens, L.; Allan, I.J.; Brant, J.; Jones, L.; Kraus, U.R.; et al. Passive sampling in regulatory chemical monitoring of nonpolar organic compounds in the aquatic environment. Environ. Sci. Technol. 2016, 50, 3-17. [CrossRef]

12. Terzopoulou, E.; Voutsa, D. Active and passive sampling for the assessment of hydrophilic organic contaminants in a river basin-ecotoxicological risk assessment. Environ. Sci. Pollut. Res. Int. 2016, 23, 5577-5591. [CrossRef] [PubMed]

13. Křesinová, Z.; Petrů, K.; Lhotský, O.; Rodsand, T.; Cajthaml, T. Passive sampling of pharmaceuticals and personal care products in aquatic environments. Eur. J. Environ. Sci. 2016, 6, 43-56. [CrossRef]

14. Corada-Fernández, C.; Candela, L.; Torres-Fuentes, N.; Pintado-Herrera, M.G.; Paniw, M.; González-Mazo, E. Effects of extreme rainfall events on the distribution of selected emerging contaminants in surface and groundwater: The Guadalete River basin (SW, Spain). Sci. Total Environ. 2017, 605-606, 770-783. [CrossRef] [PubMed]

15. Mali, N.; Cerar, S.; Koroša, A.; Auersperger, P. Passive sampling as a tool for identifying micro-organic compounds in groundwater. Sci. Total Environ. 2017, 593-594, 722-734. [CrossRef]

16. Lapworth, D.J.; Lopez, B.; Laabs, V.; Kozel, R.; Wolter, R.; Ward, R.; Amelin, E.V.; Besien, T.; Claessens, J.; Delloye, F.; et al. Developing a groundwater watch list for substances of emerging concern: A European perspective. Environ. Res. Lett. 2018, 14, 035004. [CrossRef]

17. Pinasseau, L.; Wiest, L.; Fildier, A.; Volatier, L.; Fones, G.R.; Mills, G.A.; Mermillod-Blondin, F.; Vulliet, E. Use of passive sampling and high resolution mass spectrometry using a suspect screening approach to characterise emerging pollutants in contaminated groundwater and runoff. Sci. Total Environ. 2019, 672, 253-263. [CrossRef]

18. Kiefer, K.; Müller, A.; Singer, H.; Hollender, J. New relevant pesticide transformation products in groundwater detected using target and suspect screening for agricultural and urban micropollutants with LC-HRMS. Water Res. 2019, 165, 114972. [CrossRef]

19. Schymanski, E.L.; Singer, H.; Slobodnik, J.; Ipolyi, I.M.; Oswald, P.; Krauss, M.; Schulze, T.; Haglund, P.; Letzel, T.; Grosse, S.; et al. Non-target screening with high-resolution mass spectrometry: Critical review using a collaborative trial on water analysis. Anal. Bioanal. Chem. 2015, 407, 6237-6255. [CrossRef] [PubMed]

20. Trullols, E.; Ruisánchez, I.; Rius, F.X. Validation of qualitative analytical methods. TrAC Trends Anal. Chem. 2004, 23, 137-145. [CrossRef]

21. Velcárcel, M.; Cárdenas, S.; Gallego, M. Qualitative analysis revisited. Crit. Rev. Anal. Chem. 2000, 30, 345-361. [CrossRef]

22. De Brabander, H.F.; Batjoens, P.; De Wasch, K.; Courtheyn, D.; Pottie, G.; Smets, F. Qualitative or quantitative methods for residue analysis? TrAC Trends Anal. Chem. 1997, 16, 485-489. [CrossRef] 
23. Muñoz-Olivas, R. Screening analysis: An overview of methods applied to environmental, clinical and food analyses. TrAC Trends Anal. Chem. 2004, 23, 203-216. [CrossRef]

24. Simonet, B.M.; Ríos, A.; Valcárcel, M. Unreliability of screening methods. Anal. Chimica Acta 2004, 516, 67-74. [CrossRef]

25. Ellison, S.L.R.; Gregory, S. PerspectiveQuantifying uncertainty in qualitative analysis. Analyst 1998, 123, 1155-1161. [CrossRef]

26. Mil'man, B.L.; Konopel'ko, L.A. Uncertainty of qualitative chemical analysis: General methodology and binary test methods. $J$. Anal. Chem. 2004, 59, 1128-1141. [CrossRef]

27. Pulido, A.; Ruisánchez, I.; Boqué, R.; Rius, F.X. Estimating the uncertainty of binary test results to assess their compliance with regulatory limits. Anal. Chimica Acta 2002, 455, 267-275. [CrossRef]

28. Pulido, A.; Ruisánchez, I.; Boqué, R.; Rius, F.X. Uncertainty of results in routine qualitative analysis. TrAC Trends Anal. Chem. 2003, 22, 647-654. [CrossRef]

29. Valcárcel, M.; Cárdenas, S. Current and future screening systems. Anal. Bioanal. Chem. 2004, 381, 81-83. [CrossRef]

30. Magnusson, B.; Örnemark, U. Eurachem Guide: The Fitness for Purpose of Analytical Methods-A Laboratory Guide to Method Validation and Related Topics, 2nd ed. Eurachem. 2014. Available online: https:/ / www.eurachem.org.xn--ivg (accessed on 19 December 2021).

31. Alvarez, D.A.; Petty, J.D.; Huckins, J.N.; Jones-Lepp, T.L.; Getting, D.T.; Goddard, J.P.; Manahan, S.E. Development of a passive, in situ, integrative sampler for hydrophilic organic contaminants in aquatic environments. Environ. Toxicol. Chem. 2004, 23, 1640-1648. [CrossRef]

32. Van Metre, P.C.; Alvarez, D.; Mahler, B.J.; Nowell, L.; Sandstrom, M.; Moran, P. Complex mixtures of pesticides in Midwest, U.S. streams indicated by POCIS time-integrating samplers. Environ. Pollut. 2017, 220, 431-440. [CrossRef]

33. Charriau, A.; Lissalde, S.; Poulier, G.; Mazzella, N.; Buzier, R.; Guibaud, G. Overview of the Chemcatcher ${ }^{\circledR f o r}$ the passive sampling of various pollutants in aquatic environments Part A: Principles, calibration, preparation and analysis of the sampler. Talanta 2016, 148, 556-571. [CrossRef] [PubMed]

34. Lissalde, S.; Charriau, A.; Poulier, G.; Mazzella, N.; Buzier, R.; Guibaud, G. Overview of the Chemcatcher ${ }^{\circledR} f o r$ the passive sampling of various pollutants in aquatic environments Part B: Field handling and environmental applications for the monitoring of pollutants and their biological effects. Talanta 2016, 148, 572-582. [CrossRef] [PubMed]

35. Petrie, B.; Gravell, A.; Mills, G.A.; Youdan, J.; Barden, R.; Kasprzyk-Hordern, B. In situ calibration of a new chemcatcher configuration for the determination of polar organic micropollutants in wastewater effluent. Environ. Sci. Technol. 2016, 50, 9469-9478. [CrossRef] [PubMed]

36. Vermeirssen, E.L.M.; Bramaz, N.; Hollender, J.; Singer, H.; Escher, B.I. Passive sampling combined with ecotoxicological and chemical analysis of pharmaceuticals and biocides-Evaluation of three Chemcatcher ${ }^{\mathrm{TM}}$ configurations. Water Res. 2009, 43, 903-914. [CrossRef] [PubMed]

37. Valenzuela, E.F.; Menezes, H.C.; Cardeal, Z.L. New passive sampling device for effective monitoring of pesticides in water. Anal. Chim. Acta 2019, 1054, 26-37. [CrossRef] [PubMed]

38. Valenzuela, E.F.; Menezes, H.C.; Cardeal, Z.L. Passive and grab sampling methods to assess pesticide residues in water. A review. Environ. Chem. Lett. 2020, 18, 1019-1048. [CrossRef]

39. Taylor, A.C.; Fones, G.R.; Mills, G.A. Trends in the use of passive sampling for monitoring polar pesticides in water. Trends Environ. Anal. Chem. 2020, 27, e00096. [CrossRef]

40. Brielmann, H.; Kralik, M.; Humer, F.; Clara, M.; Weiss, S.; Kulscar, S.; Scharf, S.; Voerkelius, S. Identifying anthropogenic nitrogen sources in ground and surface water. In Proceedings of the International Symposium on Isotope Hydrology: Revisiting Foundations and Exploring Frontiers, Vienna, Austria, 11-15 May 2015.

41. Ahrens, L.; Daneshvar, A.; Lau, A.E.; Kreuger, J. Characterization of five passive sampling devices for monitoring of pesticides in water. J. Chromatogr. A 2015, 1405, 1-11. [CrossRef]

42. Verreydt, G.; Bronders, J.; Keer, I.V. Lab and field screening of 5 selected passive samplers for the measurement of VOC fluxes in groundwater. J. Agric. Sci. Appl. 2014, 3, 30-38. [CrossRef]

43. Togola, A.; Berho, C.; Bruchet, A.; Robert, S. POCIS for pesticide monitoring in groundwaters: From "low flow" lab calibration to in situ monitoring. In Proceedings of the SETAC Europe 25th Annual Meeting, Barcelona, Spain, 3-7 May 2015.

44. McHugh, T.E.; Kulkarni, P.R.; Newell, C.J.; Britt, S.L. Methods for Minimization and Management of Variability in Long Term Groundwater Monitoring Results; Technical Report, No. ER-201209; U.S. Department of Defense: Washington, DC, USA, $2015 ;$ p. 50.

45. Roll, I.B.; Halden, R.U. Critical review of factors governing data quality of integrative samplers employed in environmental water monitoring. Water Res. 2016, 94, 200-207. [CrossRef] [PubMed]

46. Sophie, L.-F.; Brieudes, V.; Lalere, B.; Candido, P.; Couturier, G.; Budzinski, H.; Lavison-Bompard, G. For more reliable measurements of pharmaceuticals in the environment: Overall measurement uncertainty estimation, QA/QC implementation and metrological considerations. A case study on the Seine River. TrAC Trends Anal. Chem. 2016, 77, 76-86.

47. Criquet, J.; Dumoulin, D.; Howsam, M.; Mondamert, L.; Goossens, J.-F.; Prygiel, J.; Billon, G. Comparison of POCIS passive samplers vs. composite water sampling: A case study. Sci. Total Environ. 2017, 609, 982-991. [CrossRef] [PubMed]

48. Kaserzon, S.L.; Vijayasarathy, S.; Bräunig, J.; Mueller, L.; Hawker, D.W.; Thomas, K.V.; Mueller, J. Calibration and validation of a novel passive sampling device for the time integrative monitoring of per- and polyfluoroalkyl substances (PFASs) and precursors in contaminated groundwater. J. Hazard. Mater. 2018, 366, 423-431. [CrossRef] [PubMed] 
49. Pinasseau, L.; Wiest, L.; Volatier, L.; Fones, G.R.; Mills, G.A.; Mermillod-Blondin, F.; Vulliet, E. Calibration and field application of an innovative passive sampler for monitoring groundwater quality. Talanta 2019, 208, 120307. [CrossRef] [PubMed]

50. Musa Abubakar, T.; Amimul, A.; Abubakar, S.; Moetaz, E.; Arunkumar, T.; Bipin, J.; Razzaque, M.; Norsyahariati, N. A review on activated carbon: Process, application and prospects. J. Adv. Civ. Eng. Pract. Res. 2016, 2, 7-13.

51. Boopathy, R.; Sekar, K.; Asit, M.; Ganesan, S. Adsorption of ammonium ion by coconut shell-activated carbon from aqueous solution: Kinetic, isotherm, and thermodynamic studies. Environ. Sci. Pollut. Res. 2012, 20, 533-542. [CrossRef]

52. Rivera, J.; Ventura, F.; Caixach, J.; De Torres, M.; Figueras, A.; Guardiola, J. GC/MS, HPLC and FAB mass spectrometric analysis of organic micropollutants in Barcelona's water supply. Int. J. Environ. Anal. Chem. 1987, 29, 15-35. [CrossRef]

53. Kadokami, K.; Koga, M.; Otsuki, A. Gas chromatography-mass spectrometric determination of traces of hydrophilic and volatile organic compounds in water after preconcentration with activated carbon. Anal. Sci. 1990, 6, 843-849. [CrossRef]

54. Seethapathy, S.; Górecki, T.; Li, X. Passive sampling in environmental analysis. J. Chromatogr. A 2008, 1184, 234-253. [CrossRef]

55. Hale, E.S.; Tomaszewski, E.J.; Luthy, G.R.; Werner, D. Sorption of dichlorodiphenyltrichloroethane (DDT) and its metabolites by activated carbon in clean water and sediment slurries. Water Res. 2009, 43, 4336-4346. [CrossRef]

56. Nyoni, H.; Chimuka, L.; Vrana, B.; Cukrowska, E. Membrane assisted passive sampler for triazine compounds in water bodiesCharacterization of environmental conditions and field performance. Anal. Chim. Acta 2011, 694, 75-82. [CrossRef] [PubMed]

57. Metcalfe, C.D.; Beddows, P.A.; Bouchot, G.G.; Metcalfe, T.L.; Li, H.; Van Lavieren, H. Contaminants in the coastal karst aquifer system along the Caribbean coast of the Yucatan Peninsula, Mexico. Environ. Pollut. 2011, 159, 991-997. [CrossRef] [PubMed]

58. Tapie, N.; LeMenacha, K.; Pasquaudb, S.; Elieb, P.; Deviera, M.H.; Budzinski, H. PBDE and PCB contamination of eels from the Gironde estuary: From glass eels to silver eels. Chemosphere 2011, 83, 175-185. [CrossRef] [PubMed]

59. Berho, C.; Togola, A.; Coureau, C.; Ghestem, J.P.; Amalric, L. Applicability of polar organic compound integrative samplers for monitoring pesticides in groundwater. Environ. Sci. Pollut. Res. 2013, 20, 5220-5228. [CrossRef] [PubMed]

60. Ibrahim, I.; Togola, A.; Gonzalez, C. In-situ calibration of POCIS for the sampling of polar pesticides and metabolites in surface water. Talanta 2013, 116, 495-500. [CrossRef] [PubMed]

61. Vrana, B.; Klucarova, V.; Benicka, E.; Abou-Mrad, N.; Amdany, R.; Horakova, S.; Draxler, A.; Humer, F.; Gans, O. Passive sampling: An effective method for monitoring seasonal and spatial variability of dissolved hydrophobic organic contaminants and metals in the Danube River. Environ. Pollut. 2014, 184, 101-112. [CrossRef]

62. Silvani, L.; Riccardi, C.; Eek, E.; Papini, M.P.; Morin, N.A.; Cornelissen, G.; Oen, A.M.; Hale, S.E. Monitoring alkylphenols in water using the polar organic chemical integrative sampler (POCIS): Determining sampling rates via the extraction of PES membranes and Oasis beads. Chemosphere 2017, 184, 1362-1371. [CrossRef]

63. Morin, N.A.O.; Mazzella, N.; Arp, H.P.H.; Randon, J.; Camilleri, J.; Wiest, L.; Coquery, M.; Miège, C. Kinetic accumulation processes and models for 43 micropollutants in "pharmaceutical" POCIS. Sci. Total Environ. 2018, 615, 197-207. [CrossRef]

64. Stuart, M.; Lapworth, D.; Crane, E.; Hart, A. Review of risk from potential emerging contaminants in UK groundwater. Sci. Total Environ. 2012, 416, 1-21. [CrossRef]

65. Manamsa, K.; Crane, E.; Stuart, M.; Talbot, J.; Lapworth, D.; Hart, A. A national-scale assessment of micro-organic contaminants in groundwater of England and Wales. Sci. Total Environ. 2016, 568, 712-726. [CrossRef]

66. Shareef, A.; Parnis, C.J.; Angove, M.J.; Wells, J.D.; Johnson, B.B. Suitability of N,O-bis(trimethylsilyl)trifluoroacetamide and $\mathrm{N}$-(tert-butyldimethylsilyl)-N methyltrifluoroacetamide as derivatisation reagents for the determination of the estrogens estrone and $17 \alpha$-ethinylestradiol by gas chromatography-mass spectrometry. J. Chromatogr. A 2004, 10, 295-300. [CrossRef] [PubMed]

67. Auersperger, P.; Lah, K.; Kus, J.; Marsel, J. High precision procedure for determination of selected herbicides and their degradation products in drinking water by solid-phase extraction and gas chromatography-mass spectrometry. J. Chromatogr. A 2005, 1088, 234-241. [CrossRef] [PubMed]

68. Žlebnik, L. Pleistocene deposits of the Kranj, Sora, and Ljubljana fields. Geologija 1971, 14, 5-51. (In Slovenian)

69. Drobne, F.; Mencej, Z.; Brilly, M. Preveritve in Dopolnitve Strokovnih Osnov za Določitev Varstvenih Pasov Sedanjih in Perspektivnih Vodnih Virov za Območje Mesta Ljubljane in Okolice; Delovno Poročilo Inštituta za Geologijo, Geotehniko in Geofiziko: Ljubljana, Slovenia, 1997.

70. Urbanc, J.; Jamnik, B. Porazdelitev in izvor nitratov v podzemni vodi ljubljanskega polja. Geologija 2007, 50, 467-475. [CrossRef]

71. Jamnik, B.; Urbanc, J. Origin and guality of groundwater from Ljubljansko polje. RMZ Mater. Geoenviron. 2000, 47, 167-178.

72. Postigo, C.; Martinez, D.E.; Grondona, S.; Miglioranza, K.S.B. Groundwater pollution: Sources, mechanisms, and prevention A2. In Encyclopedia of the Anthropocene; Dellasala, D.A., Goldstein, M.I., Eds.; Elsevier: Oxford, UK, 2018; pp. 87-96.

73. European Commission (EC). Commission decision of 10 March 2004 concerning the non-inclusion of atrazine in Annex I to Council Directive 91/414/EEC and the withdrawal of authorisations for plant protection products containing this active substance 2004/247/EC. Off. J. Eur. Union. 2004, 248, 50-55.

74. Jamnik, B.; Žitnik, M. Letno Poročilo o Skladnosti Pitne Vode na Oskrbovalnem Območju v Upravljanju Javnega Podjetja VodovodKanalizacija d.o.o. v Letu 2017; Javno Podjetje Vodovod-Kanalizacija d.o.o.: Ljubljana, Slovenia, 2018.

75. Trček, B.; Žigon, D.; Kramarič Zidar, V.; Auersperger, P. The fate of benzotriazole pollutants in an urban oxic intergranular aquifer. Water Res. 2018, 131, 264-273. [CrossRef] 